\title{
Conserved Chromosome 2q31 Conformations Are Associated with Transcriptional Regulation of GAD1 GABA Synthesis Enzyme and Altered in Prefrontal Cortex of Subjects with Schizophrenia
}

\author{
Rahul Bharadwaj, ${ }^{1,2}$ Yan Jiang, ${ }^{3}$ Wenjie Mao, ${ }^{1,2}$ Mira Jakovcevski, ${ }^{4}$ Aslihan Dincer, ${ }^{3}$ Winfried Krueger, ${ }^{5}$ \\ Krassimira Garbett, ${ }^{6}$ Catheryne Whittle, ${ }^{2}$ Jogender Singh Tushir, ${ }^{2}$ Jia Liu, ${ }^{3}$ Adolfo Sequeira, ${ }^{7}$ Marquis P. Vawter, ${ }^{7}$ \\ Paul D. Gardner, ${ }^{2}$ Patrizia Casaccia, ${ }^{3}$ Theodore Rasmussen, ${ }^{5}$ William E. Bunney Jr, ${ }^{7}$ Karoly Mirnics, ${ }^{6}$ Kensuke Futai, ${ }^{2}$ \\ and Schahram Akbarian ${ }^{2,3}$ \\ ${ }^{1}$ Graduate School of Biomedical Sciences and ${ }^{2}$ Brudnick Neuropsychiatric Research Institute, University of Massachusetts Medical School, Worcester, \\ Massachusetts 01655, ${ }^{3}$ Departments of Psychiatry and Neuroscience, Friedman Brain Institute, Icahn School of Medicine at Mount Sinai, New York, \\ New York 10029, ${ }^{4}$ Max Planck Institute of Psychiatry, 80804 Munich, Germany, ${ }^{5}$ Center for Regenerative Biology and Department of Pharmaceutical \\ Sciences, University of Connecticut, Storrs, Connecticut 06269, ${ }^{6}$ Department of Psychiatry, Vanderbilt University, Nashville, Tennessee 37232, and \\ ${ }^{7}$ Department of Psychiatry and Human Behavior, University of California, Irvine, California 92697
}

Little is known about chromosomal loopings involving proximal promoter and distal enhancer elements regulating GABAergic gene expression, including changes in schizophrenia and other psychiatric conditions linked to altered inhibition. Here, we map in human chromosome 2q31 the 3D configuration of $200 \mathrm{~kb}$ of linear sequence encompassing the GAD1 GABA synthesis enzyme gene locus, and we describe a loop formation involving the GAD1 transcription start site and intergenic noncoding DNA elements facilitating reporter gene expression. The GAD1-TSS ${ }^{-50 k b L o o p}$ was enriched with nucleosomes epigenetically decorated with the transcriptional mark, histone $\mathrm{H} 3$ trimethylated at lysine 4 , and was weak or absent in skin fibroblasts and pluripotent stem cells compared with neuronal cultures differentiated from them. In the prefrontal cortex of subjects with schizophrenia, GAD1-TSS ${ }^{-50 k b L o o p}$ was decreased compared with controls, in conjunction with downregulated GAD1 expression. We generated transgenic mice expressing Gad2 promoter-driven green fluorescent protein-conjugated histone $\mathrm{H} 2 \mathrm{~B}$ and confirmed that Gad1-TSS ${ }^{-55 k b L o o p}$, the murine homolog to GAD1-TSS ${ }^{-50 k b L o o p}$, is a chromosomal conformation specific for GABAergic neurons. In primary neuronal culture, Gad1-TSS ${ }^{-55 k b L o o p}$ and Gad1 expression became upregulated when neuronal activity was increased. We conclude that 3D genome architectures, including chromosomal loopings for promoter-enhancer interactions involved in the regulation of GABAergic gene expression, are conserved between the rodent and primate brain, and subject to developmental and activity-dependent regulation, and disordered in some cases with schizophrenia. More broadly, the findings presented here draw a connection between noncoding DNA, spatial genome architecture, and neuronal plasticity in development and disease.

\section{Introduction}

Psychosis and defective cognition in some cases with schizophrenia and bipolar disorder are thought to be rooted in molecular and cellular defects of the cortical inhibitory (GABAergic) circuitry, resulting in altered synchronization of electrical activity

\footnotetext{
Received March 20, 2013; revised May 16, 2013; accepted June 12, 2013.

Author contributions: R.B., J.L., P.D.G., K.F., and S.A. designed research; R.B., Y.J., W.M., C.W., J.S.T., and J.L. performed research; W.K., K.G., C.W., A.S., M.P.V., P.C., T.R., W.E.B., and K.M. contributed unpublished reagents/ analytic tools; R.B., Y.J., W.M., M.J., and A.D. analyzed data; R.B. and S.A. wrote the paper.

This work was supported by National Institutes of Health Grants R01 MH09332, R21NS076958, and P50MH096890, and by the Brain \& Behavior Research Foundation. We thank Dr. Yin Guo for excellent technical assistance.

The authors declare no competing financial interests.

Correspondence should be addressed to Dr. Schahram Akbarian, Department of Psychiatry, Friedman Brain Institute, Icahn School of Medicine at Mount Sinai, New York, NY 10029. E-mail: Schahram.akbarian@mssm.edu. DOI:10.1523/JNEUROSCI.1252-13.2013

Copyright $\odot 2013$ the authors $\quad 0270-6474 / 13 / 3311839-13 \$ 15.00 / 0$
}

across widespread brain regions (Fatemi et al., 2005; Zhang et al., 2008; Lewis et al., 2012; Uhlhaas and Singer, 2012). The empirical framework for this hypothesis is based, among others, on a large body of postmortem literature reporting downregulated RNA and protein levels for the rate-limiting GABA synthesis enzyme, $67 \mathrm{kDa}$ glutamic acid decarboxylase (GAD67), in multiple subtypes of cortical interneurons, including those commonly defined as fastspiking, parvalbumin ${ }^{+}\left(\mathrm{PV}^{+}\right)$, and low-treshold spiking somatostatin $^{+}$cells (Akbarian and Huang, 2006; Fung et al., 2010; Konradi et al., 2011a; Schmidt and Mirnics, 2012). There is evidence that $30 \%$ or $40 \%$ of subjects with schizophrenia are affected by a more robust deficit in cortical gene expression, affecting GAD67, the transcription factor LHX6, and various neuropeptides selectively expressed by interneurons (Volk et al., 2012).

Of note, single nucleotide polymorphisms in the proximal GAD1 promoter confer genetic risk for schizophrenia, impaired 
working memory performance, and accelerated loss of gray matter (Addington et al., 2005; Straub et al., 2007), possibly in conjunction with altered expression of the cation chloride cotransporters NKCC1/KCC2, two key regulators of postsynaptic $\mathrm{GABA}_{\mathrm{A}}$ receptor-mediated currents (Hyde et al., 2011). These findings, in conjunction with altered chromatin structures at the proximal $G A D 1$ promoter, including a shift from open toward repressive chromatin-associated histone modifications and abnormal DNA methylation signatures (Huang et al., 2007; Tang et al., 2011; Grayson and Guidotti, 2012), firmly point to transcriptional dysregulation as a key factor for GABAergic dysfunction in schizophrenia. However, the regulation of gene expression in a vertebrate cell goes far beyond the genetic and epigenetic architectures of proximal promoters and transcription start sites (TSSs). Instead, chromosomes and gene expression units inside the cell nucleus are organized as highly complex dynamic 3D structures that includes chromosomal loopings via direct physical interactions of enhancer and promoter elements with TSSs (Deng and Blobel, 2010; Ribeiro de Almeida et al., 2011; Singh et al., 2012). To date, however, the regulation of supranucleosomal and higher-order chromatin structures, beyond the level of DNA methylation and post-translational modifications of the core histones (which together with 146 bp of DNA wrapped around them comprise the nucleosome as the fundamental unit of chromatin), essentially remains unexplored in normal or diseased human brain.

Here, we explore 3D chromosomal architectures encompassing $200 \mathrm{~kb}$ of chromosome $2 \mathrm{q} 31$ in prefrontal cortex (PFC) of subjects with schizophrenia and controls, cultured human and mouse (chromosome 2qC2) neurons and their pluripotent precursors, and in transgenic animals tagged for GABAergic chromatin. We identify, for the first time, conserved regulatory DNA elements in rodent and primate genomes that are engaged in a loop formation with the GAD1/Gad1 TSS and present multiple lines of evidence that dynamic regulation of 3D genome structures plays a critical role for orderly development and function of GABAergic systems in the human brain.

\section{Materials and Methods}

iPS reprogramming of human dermal fibroblasts. Fibroblasts from a 43year-old (hDF6, ATCC) healthy female were reprogrammed using a published protocol (Maherali et al., 2008) with minor modifications. Briefly, passage 6 cells were reprogrammed by infection of $3 \times 10^{5}$ fibroblasts with a mixture of lentivirus particles (Openbiosystems) containing genomes encoding OCT4, SOX2, KLF4, and human c-MYC at a multiplicity of infection of 5:5:5:2.5 (hDF6). Infected cells were grown for $4 \mathrm{~d}$ in fibroblast growth medium (DMEM/10\% FCS), but $3 \mathrm{~d}$ after infection, each 100,000 fibroblasts were passaged into $10 \mathrm{~cm}$ tissue culture dishes and grown on feeder cells until candidate colonies were harvested. On day 4, the fibroblast growth medium was replaced with human ES cell medium (80\% DMEM/F12) (Invitrogen), 20\% knock-out serum replacement (Invitrogen), $1 \times$ nonessential amino acids (Invitrogen), $1 \mathrm{~mm}$ glutamine (Invitrogen), $100 \mu \mathrm{M} \beta$-mercaptoethanol (Invitrogen), and 5 $\mathrm{ng} / \mathrm{ml}$ fibroblast growth factor 2 (FGF2) (R\&D Systems). The culture medium was replaced daily until all candidate colonies were harvested. This approach yielded colonies with embryonic stem cell morphology at a frequency of $8 \times 10^{-5}$ (data not shown). From day 30 onwards, candidate iPS cell colonies were harvested using glass knives (Vitrolife), transferred into culture wells of 6-well plate containing fresh mouse embryonic fibroblast feeder cells and expanded to colonies with a diameter of 1-2 mm. Candidate iPS cells with a modal chromosome number of 46 were then maintained further feeder free conditions on Matrigel in the presence of MTESR1.

Assessment of pluripotency. Pluripotency was determined initially by immunofluorescent detection of endogenous expression of Nanog and
Tra1-60. Surface pluripotency marker expression for Tra1-60 and SSEA4 was confirmed using fluorescence activated cell sorting. We next confirmed by qRT-PCR the expression of OCT4 and REX1 mRNAs. We assessed pluripotency further through targeted differentiation into all three germlayers and detection of Sox17 (endoderm), Otx2 (ectoderm), or Brachyury (mesoderm) protein expression by immunofluorescence. Finally, we also produced embryoid bodies from our iPSCs and assessed expression of Nestin and Neuropilin 2 (neuroectoderm), SOX17 and Alpha-Feto Protein (endoderm), and KDR, Matrilin 1, Myf5, and Brachyury (mesoderm). Line W(K)6 iPS was grown feeder free on Matrigel (BD Biosciences; 356231) and collected with dispase, and embroid bodies were formed using Aggrewell 400 plates (Stem Cell Technologies; 27845). After growing the iPS cells for 1-2 d, embroid bodies were collected and moved into nonadherent flasks, with HES media changed daily for $4 \mathrm{~d}$ and on the fifth day changed to neural induction (NI) media containing FGF2. On day 6, the aggregates were plated on coated tissue culture plates (poly-l-ornithine/laminin) in NI media + FGF2 and processed similar as described above for H9ESC. For chromosome conformation capture (3C) assays, $8-15 \times 10^{6}$ stem cells (or differentiated neurons, see below) were used as input.

Neuronal differentiation assays (human). Depending on the strength of the chromosomal interactions and sensitivity of the PCR assays, conventional chromosome conformation capture (3C) often requires $10^{6}$ to $10^{7}$ nuclei as input (Miele and Dekker, 2009). Therefore, we modified existing protocols to induce neural differentiation in a larger number of cells. Briefly, the W6 iPS were grown feeder free on Matrigel (BD Biosciences; 356231) and collected with dispase, and embroid bodies were formed using Aggrewell 400 plates (Stem Cell Technologies; 27845). After growing the iPS cells for $1-2 \mathrm{~d}$, embroid bodies were collected and moved into nonadherent flasks, with HES media changed daily for $4 \mathrm{~d}$ and on the fifth day changed to NI media containing FGF2. On day 6, the aggregates were plated on coated tissue culture plates (poly-L-ornithine/laminin) in NI media + FGF2, changing the media every second day. By day 11-14, neural rosettes were forming. At approximately day 14, these primary neural rosettes were mechanically removed from the plate and grown in suspension for $2 \mathrm{~d}$ in a nonadherent flask, then replated in NI + FGF2. After $2 \mathrm{~d}$, the media is changed to a modified (by the addition of N2 supplement) neural proliferation media (NP) + FGF2 + leukemia inhibitory factor (LIF) (Dhara et al., 2008). The cells are grown for a further $6-10 \mathrm{~d}$ in changing the media every second day. At approximately day $24-28$, the secondary neural rosettes were collected and grown for $2 \mathrm{~d}$ in suspension and then replated on (poly-L-ornithine/laminin) in NP media + FGF2 + LIF with the addition of $200 \mu \mathrm{M}$ Sonic hedgehog for $24 \mathrm{~h}$, grown for another $7-12 \mathrm{~d}$. Then, tertiary neural rosettes were collected in $1 \times$ HBSS, incubated for 10-30 min, and then titrated gently to break up the rosettes, and the cells replated in NP media + FGF2 + LIF with the addition of $200 \mu \mathrm{M}$ Sonic hedgehog for $24 \mathrm{~h}$. After 1-2 d, the cells are grown in neural differentiation media (Sara et al., 2005) for 6-12 d and then harvested.

Human dermal fibroblasts. Fibroblasts (from two unrelated donors, including hDF6) were grown in batches of four T175 flasks in DMEM, $15 \%$ Hyclone serum $+0.5 \mathrm{ml}$ glutamine and $1 \times$ nonessential amino acids. After confluency (day 6), cells were harvested and processed for $3 \mathrm{C}$ as above.

Postmortem brain tissue. For the clinical studies, specimens from the rostral third of the dorsolateral prefrontal cortex of 10 subjects diagnosed with schizophrenia ( 4 females $/ 5$ males, age range $40-87$ years; tissue $\mathrm{pH}$, 6.1-7.2) and 7 controls ( 2 females, 6 males; age range 41-90 years; tissue $\mathrm{pH}, 6.1-7.2)$ were included in this study. An independent set of 6 controls ( 4 females, 2 males; age range $16-81$ years), and RNA integrity number from 4.1 to 9.0 was used for RNAseq experiments. Specimens were from a brain bank at the University of California at Irvine and Davis. Procedures for tissue collection, neuropathologic examination (to rule out degenerative and neurologic disease), diagnosing schizophrenia using DSM-IV-based diagnostic criteria were described previously (Akbarian et al., 1995; Huang et al., 2007).

Generation of Gad2-H2BGFP transgenic mice. Transgenic mice were generated by injection of circular modified bacterial artificial chromosome (BAC) into fertilized C57BL/6 mouse oocytes by the University of 
California Irvine Transgenic Mouse Facility (http://www.research.uci. edu/tmf/), using BAC RP23 27D24, containing the mouse glutamate decarboxylase 2 ( $\mathrm{mGad} 2$ ) locus (chromosome 2: 22,453,784-22,682,644, NCBI Build 37.1) (http://bacpac.chori.org/), including the $m G a d 2$ gene (chromosome 2: 22,478,000-22,550,009, + strand). BAC modifications were performed to insert H2BGFP-FRT-neo-FRT at the Gad2 start codon, and then the selection marker (neomycin) cassette was removed via FRT directed recombination, the BAC modifications further confirmed with restriction mapping and sequencing.

Primary hippocampal neuron culture (mouse). All animal experiments were approved by the Animal Use and Care Committees of the participating institutions. Primary hippocampal cultures were prepared from early postnatal (P0-P1) mouse as described previously (Brewer et al., 1993) with some modifications (Futai et al., 2013). Briefly, hippocampi were dissected and trypsinized, after which neurons were dissociated and plated onto coverslips coated with poly-D-lysine $(40 \mu \mathrm{g} / \mathrm{ml})$ and laminin $(4 \mu \mathrm{g} / \mathrm{ml})$ at a density of $500 \mathrm{cell} / \mathrm{mm}^{2}$. Neurons were maintained in B27 containing medium for $14 \mathrm{~d}$ in vitro and treated with picrotoxin (100 $\mu \mathrm{M})$, tetrodotoxin $(1 \mu \mathrm{M})$, or equal volume of DMSO for $15 \mathrm{~h}$. Total RNA was extracted using RNAqueous Micro Kit (Ambion) and reverse transcribed using High Capacity RNA-to-cDNA Kit (Applied Biosystems). Real-time quantitative PCR was then performed on an ABI 7500 Fast sequence detection system (Applied Biosystems) using TaqMan assay (Applied Biosystems). Gene expression levels in drug-treated groups or control groups (DMSO-treated) were analyzed in 3 independent cultures in PCR duplicates. Glyceraldehyde-3-phosphate-dehydrogenase (Gapdh) was used as reference gene, and fold change of Gad1 expression level in drug-treated groups relative to control group was determined using the $2^{-\Delta \Delta C_{T}}$ method $\left[\Delta \Delta \mathrm{C}_{\mathrm{T}}\right.$ values $=\left(\mathrm{C}_{\mathrm{Tgad} 1}-\mathrm{C}_{\text {Tgapdh }}\right)_{\text {treated }}-$ $\left.\left(\mathrm{C}_{\text {Tgad1 }}-\mathrm{C}_{\text {Tgapdh }}\right)_{\text {control }}\right]$ (Livak and Schmittgen, 2001).

Antipsychotic drug treatment. For antipsychotic drug studies, adult male C57BL/6J mice, 10-15 weeks of age, were treated acutely or for $21 \mathrm{~d}$ with once daily intraperitoneal injections of saline or haloperidol $(0.5$ $\mathrm{mg} / \mathrm{kg}$ ) or clozapine $(5 \mathrm{mg} / \mathrm{kg}$ ) (Sigma). Tissue (PFC) was harvested 60 min after the last treatment.

Immunohistochemistry. Gad2-H2BGFP mice were anesthetized and perfused transcardially with cold $4 \%$ PFA in $1 \times$ PBS. Brains were harvested and postfixed in 4\% PFA overnight and then cryoprotected in 30\% sucrose in $0.1 \mathrm{~m}$ PBS. Brains were sectioned $30 \mu \mathrm{m}$ thick on a freezing microtome. Immunostaining was done with free-floating sections using Tyramide-Plus signal amplification system. Briefly, sections were incubated with primary antibodies against calretinin (1:1000, SWANT) or parvalbumin (1:1000, SWANT), followed by biotin-tagged secondary antibody incubation (1:200; Jackson ImmunoResearch Laboratories), ABC (Vector Laboratories) treatment, and Tyramide-Plus signal amplification (1:50, PerkinElmer Life and Analytical Science). Sections were mounted to slides using VECTASHIELD mounting medium with DAPI.

Chromosome conformation capture (3C). Cerebral cortex (300-500 mg of gray matter/specimen) was homogenized in $1 \times$ PBS-buffered, $1.5 \%$ formaldehyde to cross-link higher-order chromatin (of note, based on flow cytometry of purified nuclei from postmortem specimens, there are at least $3-4 \times 10^{6}$ physically intact nuclei in a $300 \mathrm{mg}$ piece of cortical gray matter) (Jiang et al., 2008). After 15 min, cross-linking was stopped by the addition of glycine to $0.125 \mathrm{M}$ final concentration) and samples spun in a tabletop centrifuge $\mathrm{c}$ at $4000 \mathrm{rpm}$ for $10 \mathrm{~min}$ at $4^{\circ} \mathrm{C}$; then the pellet was resuspended in $2 \mathrm{ml}$ of cellular lysis buffer $(10 \mathrm{~mm}$ Tris- $\mathrm{HCl}$, $\mathrm{pH} 8.0 / 10 \mathrm{~mm} \mathrm{NaCl} / 0.2 \%$ Ige cal CA630) and incubated at room temperature for $45 \mathrm{~min}$. Next, samples were homogenized by constant pipetting and spun at $5000 \mathrm{rpm}$ for $5 \mathrm{~min}$, the supernatant removed and the pelleted nuclei stored at $-80^{\circ} \mathrm{C}$.

Cell culture. Media was aspirated, followed by a quick wash with $37^{\circ} \mathrm{C}$ $1 \times$ PBS. Then $5 \mathrm{ml}$ of $1 \times \mathrm{PBS} / 1.5 \%$ formaldehyde was added to the cultures, the cells scrapped, and kept in suspension for $10 \mathrm{~min}$. Then cross-linking was stopped by the addition of glycine to $0.125 \mathrm{~m}$ and cells harvested by centrifugation at $1200 \mathrm{rpm} / 5 \mathrm{~min}$. The pellet is treated with $1 \times$ cellular lysis buffer after adding one-tenth volume of protease inhibitor mixture (Sigma), resuspended, and left at room temperature for 15 $\mathrm{min}$, followed by homogenization and nuclei pelleting (5000 rpm for 5 min) and two washes with $1 \times$ New England Biolabs2 [NEB2] restriction enzyme buffer).

Restriction digestion. Nuclei were resuspended in $250 \mu$ l of $1 \times$ NEB2, divided into $5 \times 50 \mu$ laliquots, to each of which $312 \mu \mathrm{l}$ of $1 \times \mathrm{NEB} 2$ and $38 \mu \mathrm{l}$ of $1 \%$ SDS were added, followed by gentle mixing and incubation at $65^{\circ} \mathrm{C}$ for $10 \mathrm{~min}$ to remove proteins that are not directly associated with DNA and facilitate more efficient digestion. Then, $44 \mu \mathrm{l}$ of Triton X-100 was added to each sample to quench the SDS by gentle pipetting, and samples were digested with 400 units of HindIII (NEB) at $37^{\circ} \mathrm{C}$ overnight with gentle shaking.

Ligation and reverse cross linking. To inactivate HindIII, $86 \mu \mathrm{l}$ of $10 \%$ SDS (Bio-Rad) was added and samples were incubated at $65^{\circ} \mathrm{C}$ for 30 $\mathrm{min}$. Then, each sample was added to $7.61 \mathrm{ml}$ of ligation reaction mixture. Each mixture consisted of $745 \mu \mathrm{l}$ of $10 \%$ Triton X-100, $745 \mu \mathrm{l}$ of $10 \times$ ligation buffer [ $1 \mathrm{~m}$ Tris $\mathrm{HCl}, \mathrm{pH} 7.5,1 \mathrm{M} \mathrm{MgCl}_{2}, 1 \mathrm{~m} \mathrm{DTT}$ dithiothreitol (Bio-Rad)], $80 \mu \mathrm{l}$ of $10 \mathrm{mg} / \mathrm{ml}$ bovine serum albumin (NEB), 80 $\mu \mathrm{l}$ of $100 \mathrm{~mm}$ ATP (Sigma) and $5960 \mu \mathrm{l}$ of $\mathrm{H}_{2} \mathrm{O}$. To each mixture, $50 \mu \mathrm{l}$ of T4 DNA ligase ( $1 \mathrm{U} / \mu \mathrm{l}$; Invitrogen) was added and incubated at $16^{\circ} \mathrm{C}$ for $4 \mathrm{~h}$ followed by reverse cross-linking at $65^{\circ} \mathrm{C}$ overnight with simultaneous Proteinase K digestion [ $50 \mu \mathrm{l}$ of $10 \mathrm{mg} / \mathrm{ml}$ Proteinase K (Sigma) reconstituted with TE buffer $\mathrm{pH} 8.0$ ] to digest chromatin-associated proteins. To improve ligated DNA recovery, another $50 \mu \mathrm{l}$ of Proteinase $\mathrm{K}$ was added and incubated at $65^{\circ} \mathrm{C}$ for $2 \mathrm{~h}$.

DNA purification and recovery. Ligated samples were phenol extracted ( $\mathrm{pH}$ 8.0, Fisher) followed by phenol-chloroform (1:1) ( $\mathrm{pH}$ 8.0, Omnipur) followed by ethanol precipitation. DNA was dissolved in $1 \times \mathrm{TE}$ buffer ( $\mathrm{pH}$ 8.0).

For 3C studies in Gad2-H2BGFP transgenic mice, $0.2-0.3 \times 10^{6}$ $\mathrm{GFP}^{+}$nuclei and $48 \times 10^{6} \mathrm{GFP}^{-}$nuclei were separately sorted and collected from cerebral cortex using fluorescence-activated nuclei sorting as described previously (Jiang et al., 2008). Additional 3C studies were conducted in whole cortex of adult C57BL/6J wild-type mice or on the primary neuronal cultures described above.

3C quantification. We mapped physical interactions of noncontiguous DNA elements within a $200 \mathrm{~kb}$ region of chromosome chromosome 2 (171,573,000-171,797,000; HG19), encompassing GAD1 (Fig. 1) by PCR across the ligation junctions of interacting fragments. Primers were designed according to 3C guidelines (Miele and Dekker, 2009), with $30 \mathrm{bp}$ in length and positioned within $60 \mathrm{bp}$ of the restriction enzyme cut site, a melting temperature of $60^{\circ} \mathrm{C}$, and with a GC\% content of $45 \%$. From a total of 55 HindIII fragments, 11 fragments yielding primer sequences in accordance with these primer selection criteria were probed by specific primers positioned in the $5^{\prime}$ to $3^{\prime}$ direction on the sense strand amplifying toward the end of the respective restriction fragment were used. The anchor primer for all PCR represented the HindIII fragment containing the TSS of GAD1. All primers were 30-32 nt in length, melting temperature $=60^{\circ} \mathrm{C}$, and positioned $<200 \mathrm{bp}$ from a HindIII restriction site. PCR products were resolved in agarose gels and the level of interaction between any two fragments in the $3 \mathrm{C}$ libraries measured semiquantitatively. To this end, amplicons generated by PCR across a single ligation junction run in triplicate on $2 \%$ agarose/1xTAE/130V/25 min and band intensities measured by UVP Bioimaging system/Labworks version 4.5 software, after background subtractions from blank gel regions. We used a BAC (clone ID-RP11-570C16, representing chromosome 2: 171552700-171745852; http://bacpac.chori.org) to control for primer efficiency (Dekker, 2006; Miele and Dekker, 2009). To control for ligation efficiencies across independent $3 \mathrm{C}$ experiments/samples, we mapped physical interactions of noncontiguous DNA elements within 75 $\mathrm{kb}$ of chromosome $16(62,275,000-62,350,000$; HG19) in a previously described "gene desert" region with the two nearest genes (CDH8 and CDH11) located $200 \mathrm{~kb}$ upstream and $2.6 \mathrm{Mb}$ downstream (Ferraiuolo et al., 2010).

Furthermore, we mapped physical interactions of noncontiguous DNA elements within a $70 \mathrm{~kb}$ region of chromosome mouse chr2qC2 (chromosome 2: 70,340,000-70,410,069; $\mathrm{mm} 9$ ), to interrogate loop formations of DNA sequences positioned up to $100 \mathrm{~kb}$ upstream of Gad1 TSS.

Promoter/enhancer assays. Luciferase reporter gene assays were performed using the minimal promoter (TATA box) luciferase vector 

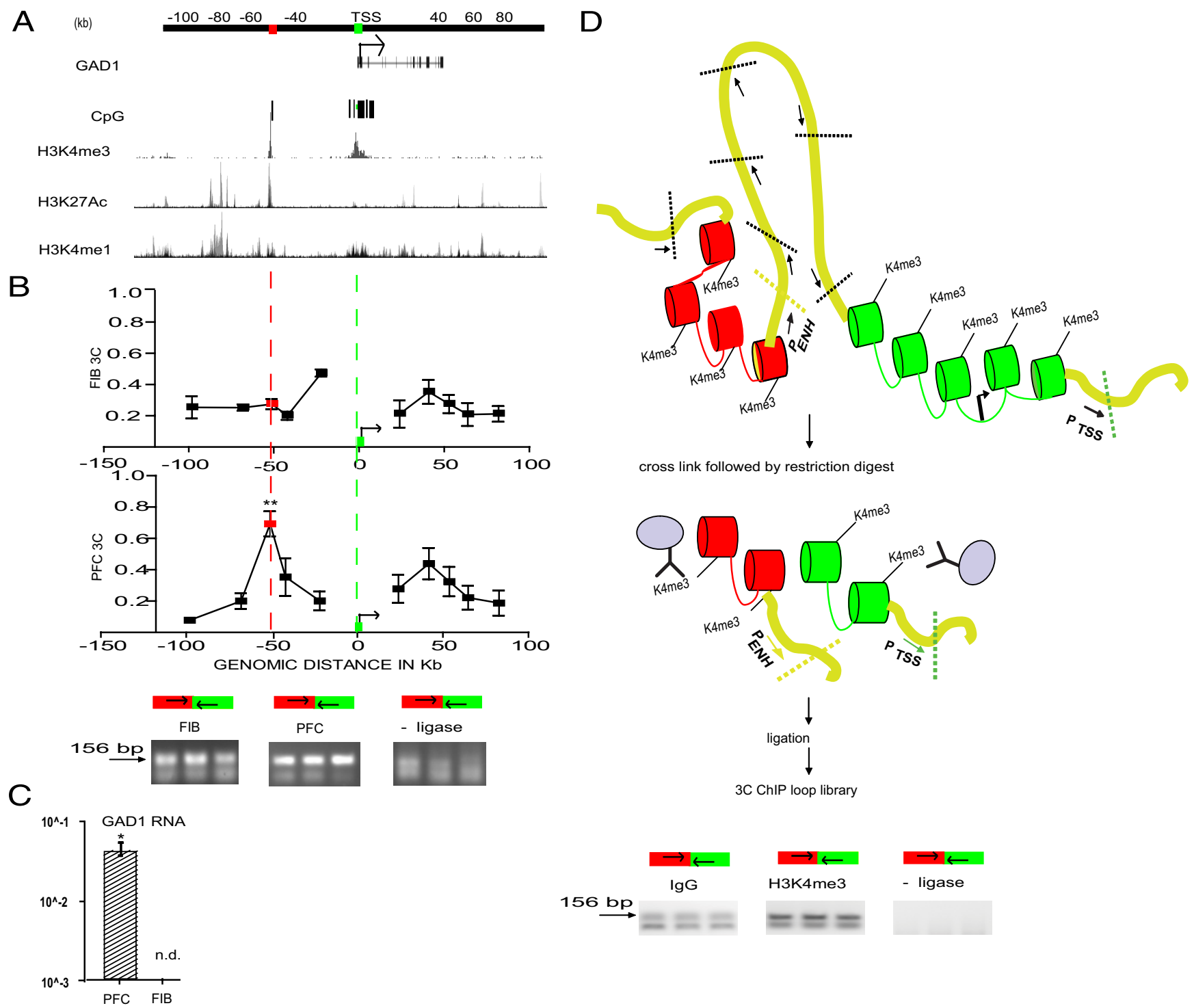

cross link followed by restriction digest
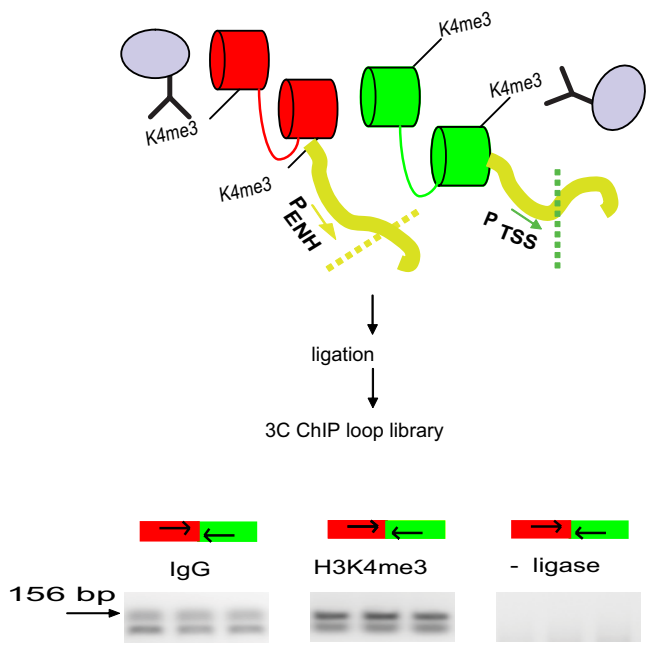

Figure 1. Chromosome $2 q 31$ conformation at the GAD1 locus. A, Genome map for $200 \mathrm{~kb}$ surrounding GAD1 TSS, including $50 \mathrm{~kb}$ GAD1 gene body and surrounding sequences as indicated. Browser tracks showing H3K4me3 landscape at 2 q31 in PFC neurons, and H3K27ac and H3K4me1 (composite ChIP-seq tracks from 3 ENCODE cell lines). Red and green boxes represent two HindIII restriction fragments that harbor sharp H3K4me3 peaks in PFC neurons. $\boldsymbol{B}, x$-y graphs present chromosome conformation capture (3C) profiles across the $200 \mathrm{~kb}$ portion of chromosome $2 q 31$ for (top) skin fibroblasts, FIB ( $N=2$ donors) and (bottom) prefrontal cortex, PFC ( $N=4$ donors) as indicated. Each data point expresses the interaction frequency between a specific restriction fragment with the TSS. Data are mean \pm SD. 3C maps were anchored on TSS containing fragment (green). There is significant interaction (one-way ANOVA, ${ }^{* *} p<0.001$ Bonferroni corrected) between two (pG-rich, H3K4me3 decorated sequences in the PFC ( $A$, red and green boxes; and referred to as GAD1-TSS ${ }^{-50 k b L o o p}$ in the text). Representative gel images for PCR products from 3C assays, showing a specific interaction between red- and green-marked Hindlll fragment as indicated (green box represents primer $5^{\prime}$-GGGCGGGAAAGGTGCATAAAACTGAGACTGA, hg19 chromosome 2: 171675735-171675765; red box, primer 5' -GTCCTTCAAAACACGTTGCCTAGCAACAAA, hg19 chromosome 2: 171626697-171626726). C, Robust expression of GAD1 RNA in PFC but not in FIB $\left(N=3 /\right.$ tissue, mean \pm SEM, ${ }^{*} p<0.05$, Wilcoxon signed-rank test), as determined by qRT-PCR after normalization to $18 \mathrm{~s} r$ rNA. $\boldsymbol{D}$, Top, Workflow and results of $3 C$-ChIP looP experiments. Schematic illustration of 3D chromatin structures at GAD1 locus, including physical proximity between GAD1 TSS sequences (green) and putative enhancer (red) as described in $\boldsymbol{A}$, $\boldsymbol{B}$. Chromatin is formaldehyde-crosslinked, followed by HindIII restriction digest, anti-H3K4me3 immunoprecipitation, and religation and 3C PCR to map noncontiguous DNA elements. There is robust PCR-based amplification of noncontiguous DNA sequences from green- and red-marked sequences (GAD1-TSS ${ }^{-50 k b L o o p}$ ) but only weak or nondetectable PCR signal in controls (lgG pulldown with ligase and H3K4me3 pulldown without ligase treatment).

(pGL4.23 [luc2/minP] vector; Promega; E8411) in HEK-293 cell cultures. Specifically, 115 bp (chromosome 2: 171622200-171622315) was cloned into the multiple cloning site of the luciferase vector and sequenceverified clones transfected into HEK-293 cells with Lipofectamine-2000 (Invitrogen). Furthermore, control plasmids were generated with a $125 \mathrm{bp}$ sequence (chromosome 2: 171645000-171645125) from an upstream region restriction fragment that was not surrounded by H3K4me1 or H3K27ac peaks in various Encyclopedia of DNA Elements Consortium (ENCODE) cell lines and did not harbor AP-1 motifs. As an additional control, Renilla luciferase vector (Prl-TK; Promega; E2241) was cotransfected into every well to correct for variations in transfection efficiency. Cells were harvested and lysed $48 \mathrm{~h}$ after transfection using lysis buffer from the Promega luciferase assay kit (catalog \#E1910) and firefly luciferase units quantified (kit luciferase substrate) using the Bio-Rad luminometer followed by measurement of Renilla luciferase units by chemiluminescence (kit Stop\& Glo reagent) according to the manufacturer's protocol. Relative luciferase units were calculated relative to minimal TATA box driven luciferase units.

3 C-ChIP loop. Cross-linked nuclei were restriction digested as described in the 3C method using HindIII (NEB) enzyme. Digested restriction fragments were then washed with FSB (20 mM Tris-Cl, pH 7.5, 5 mM EDTA, $50 \mathrm{~mm} \mathrm{NaCl}$ final concentration) followed by immunoprecipitation (anti-H3K4me3 $1 \mu \mathrm{g} / \mu \mathrm{l} ; 1: 1000$ dilution; ab8898, Abcam) at $4^{\circ} \mathrm{C}$ 
overnight in FSB with phenyl methyl sulfonyl fluoride $(0.1 \mu \mathrm{M}$ final concentration), dithiothreitol ( $3 \mu \mathrm{M}$ final concentration), and benzamidine $(0.1 \mu \mathrm{M}$ final concentration). Antibody-chromatin complexes were then isolated using protein $\mathrm{G}$ agarose slurry followed by elution as described previously (Huang et al., 2007). The immunoprecipitated chromatin fragments were then ligated with T4 DNA ligase (Invitrogen) as in the $3 \mathrm{C}$ protocol step. Ligated fragments were then reverse cross-linked and digested with Proteinase K (Invitrogen, catalog \#25530-031) and purified to generate the 3C-ChIP loop library using phenol/phenolchloroform extraction followed by ethanol precipitation as in 3C. Quantification of interacting fragments from $\mathrm{H} 3 \mathrm{~K} 4 \mathrm{me} 3 \mathrm{ChIP}-3 \mathrm{C}$, and for control, IgG-3C and H3K4me3 ChIP-3C (no ligase) libraries was done exactly as for $3 \mathrm{C}$ quantification from conventional $3 \mathrm{C}$ assays described above. The H3K4me3 ChIP-3C, IgG-3C, and H3K4me3 ChIP-3C (no ligase) assays and libraries were processed in parallel using the same protocol and solutions.

CBP-ChIP. Chromatin from cerebral cortex from one hemisphere of adult $\mathrm{C} 57 \mathrm{BL} / 6 \mathrm{~J}$ mice $(N=3)$ was prepared by formalin crosslinking and sonication as described previously (Jiang et al., 2010), for ChIP with an antibody raised against the $\mathrm{C}$ terminus of the cAMP-response element binding protein (CREB)-binding protein (CBP/CREBBP) (Abs c-583, rabbit polyclonal, Santa Cruz Biotechnology). For PCR-based quantifications of ChIP assays, input DNA and immunoprecipitated DNA were amplified by SYBR Green-based real-time PCR. Primers were designed to interrogate four positions in the Gad1 locus, with the following chromosome 2 (mm9) coordinates: (1) 70330778-70330906, $-77 \mathrm{~kb}$ upstream of the Gad1 TSS; (2) 70352784-70352899, -55 kb to Gad1-TSS; (3) 70399957-70400075 at Gad1-TSS; and (4) 70437331-70437444, + 37 kb downstream from Gad1-TSS.

$R N A$-seq. RNA was extracted from $\sim 75-100 \mathrm{mg}$ of gray matter of 6 adult control PFC specimens with Rneasy Lipid Tissue mini kit (catalog \#74804, QIAGEN), treated with DNase I, purified, and diluted to 20 $\mathrm{ng} / \mu \mathrm{l}$. Sequencing libraries were prepared according to the NuGen Ovation RNASeq version 2 protocol, and run on the paired-end 50 bp module in Illumina HiSeq 2000 (Eurofins MWG; Operon). RNA-seq raw reads that passed the QC metric, which is called as the "chastity filter" by Illumina, were aligned to the UCSC Homo sapiens reference genome build 19 using TopHat version 1.4.0 default parameters, allowing a maximum of 2 mismatches when mapping reads to the reference and multiple alignments per read (up to 40 by default). Raw reads that passed Illumina's chastity filter varied from $22,470,801$ to $60,734,424$. TopHat uses the bowtie version 0.12 .8 algorithm to perform the alignment in first phase and then identifies potential splice junctions by using these mapping results and aligns previously unmapped reads in second phase to generate alignment files. The resulting aligned bam files were processed by SAMtools (Li et al., 2009), and the read coverage of indexed alignment files for each sample was visualized with the Integrative Genomic Viewer. For intranuclear RNAseq, FACS-sorted neuronal NeuN + nuclei (Jiang et al., 2008) $\left(>3 \times 10^{6}\right)$ from adult C57BL/6J cerebral cortex were subjected to total RNA isolation using trizol (Invitrogen) reagent. Ribsosomal and other RNAs $<200$ nt were removed using RNA clean and Concentrator kit (Zymo Research) followed by DNA digestion. A total of $20 \mathrm{ng} / \mu \mathrm{l}(10 \mu \mathrm{l}$ total $=200 \mathrm{ng}) \mathrm{RNA}$ was fragmented at $95^{\circ} \mathrm{C}$ for $5 \mathrm{~min}$ using Invitrogen fragmentation buffer (from SuperScript III). Firststrand synthesis was performed using Random primer (Invitrogen; catalog \#48190011) and Superscript III. First-strand cDNA was cleaned using Ampure XP beads followed by second-strand synthesis using dUTP mixture (dUTP $20 \mathrm{~mm}$, dATP, dCTP, dGTP $10 \mathrm{~mm}$ ) and DNA polymerase I $(10 \mathrm{U} / \mu \mathrm{l}, \mathrm{NEB})$. Double-stranded cDNA was end-repaired using Klenow DNA polymerase END-repair kit (Epicenter) followed by A-tailing and adapter ligation. Ampure XP beads were again used to purify the adapter ligated double-stranded DNA followed by UracilDNA Glycosylase (NEB, M0280S) incubation to remove dUTP containing second strand. Strand-specific single-stranded DNA was again purified using Ampure XP beads followed by PCR using adapter specific barcoded PCR primers. Purified library was confirmed using bioanalyzer high-sensitive DNA ChiP analysis followed by deep-sequencing using Illumina multiplexing protocol and bioinformatical analyses as described above.
Statistical methods. Data comparing two groups were analyzed with two-tailed $t$ tests, paired or unpaired, where appropriate. Data on GADI RNA expression in PFC versus fibroblasts (FIB) was analyzed using the Wilcoxon signed rank test. Data with more than two groups were analyzed by one-way ANOVA having either "locus" or for the picrotoxin/ tetrodoxin-based neuronal activity experiments "treatment" as between group factors, followed by Bonferroni's multiple-comparison test. The 3C data from mouse cortex of animals subjected to systemic administration of saline versus haloperidol or clozapine were analyzed by two-way ANOVA having "locus" and "treatment" as between group factors, followed by Tukey's honest significant difference test.

\section{Results}

\section{Tissue-specific chromosomal architectures at GAD1} (chromosome 2q31) locus

Cortical gray matter from the rostral frontal lobe of four adult postmortem specimens, ranging in (1) age from 58 to 81 years, (2) postmortem interval 7-11 h, and (3) tissue $\mathrm{pH}$ 6.1-7.2 was used to prepare 3C libraries from DNA ligase-treated HindIII digests, to map and quantify physical interactions of noncontiguous DNA elements by PCR. Together, we explored $200 \mathrm{~kb}$ on chromosome 2 (171,573,000-171,797,000; HG19) surrounding the GAD1 TSS (Fig. 1A).

Physical interaction frequencies from our PFC 3C assays are shown in Figure $1 B$. Because chromatin fibers are flexible, resulting in much higher interactions of neighboring restriction fragments within 20-25 kb range in 3C assays (Gheldof et al., 2006; Miele et al., 2006), we primarily interrogated physical interactions of GAD1 TSS with DNA sequences that on the linear genome are positioned $>25 \mathrm{kB}$ from the TSS. With the anchor primer on the $11.6 \mathrm{~kb}$ HindIII fragment harboring GAD1 TSS (Fig. $1 B$, green box), the $3 \mathrm{C}$ assays from the PFC consistently revealed in 4 of 4 specimens a robust interaction with a restriction fragment positioned $-50 \mathrm{~kb}$ upstream of the TSS (red box in Fig. $1 B$ ). This interaction was highly significant in the PFC $\left(F_{(9,30)}=3021, p<0.001\right.$ with Bonferroni's post hoc for multiple comparisons) and tissue specific because no evidence for this chromosomal looping was found in $3 \mathrm{C}$ assays from cultured fibroblasts from two unrelated donors (Fig. $1 B$ ). In contrast to these brain/fibroblast differences in GAD1 higher-order chromatin, the physical interaction of noncontiguous DNA elements across a $75 \mathrm{~kb}$ intergenic portion on chromosome 16 were similar between PFC and fibroblasts (mean \pm SEM: PFC, $0.30 \pm 0.02$; fibroblasts $0.32 \pm 0.01$ ). Importantly, no PCR product was observed in PFC 3C assays from the same samples when processed without the critical DNA ligase step (which conjugates noncontiguous DNA elements) before phenol extraction and DNA purification $($ Fig. $1 B$ ). These findings, together, strongly suggest that chromosome 2q31 in human PFC, but not fibroblasts, includes a loop formation (referred to as GAD1-TSS ${ }^{-50 k b L o o p}$ hereafter) between the GAD1 TSS with intergenic sequences positioned $\sim 50$ $\mathrm{kb}$ further upstream.

We noticed that both the GAD1 TSS and its looping partner sequences positioned $50 \mathrm{~kb}$ upstream of GAD1 were epigenetically decorated with sharp peaks for histone $\mathrm{H} 3$ trimethylated at lysine 4 (H3K4me3) in neuronal chromatin extracted from prefrontal cortex (Cheung et al., 2010) (Fig. 1A). The H3K4me3 modification is an epigenetic mark sharply regulated around TSSs and other regulatory sequences associated with open chromatin and active gene expression (Guenther et al., 2005, 2007). In human cerebral cortex, the H3K4me3 mark shows a preference for $\mathrm{CpG}$ enriched sequences, specifically those not tagged by DNA cytosine methylation and repressive histone marks (Maunakea et al., 2010). The H3K4me3 peak at the GAD1 TSS (Fig. 1A) 
extended across $2.5 \mathrm{~kb}$ (HG19, chromosome 2: 171,672,200-171,674,500) and included all alternative gene proximal promoters previously associated with GAD1 expression (Chen et al., 2011). Furthermore, the $-50 \mathrm{~kb}$ upstream sequence was defined by sharp peaks of histone $\mathrm{H} 3$ acetylated at lysine 27 (H3K27ac) in conjunction with a corresponding spike of histone $\mathrm{H} 3$ monomethylated at lysine 4 (H3K4me1) in ENCODE ChIP-seq tracks for $\mathrm{H} 1$ human embryonic stem cells (H1ESC), and the human umbilical vein endothelial and K562 erythroblastoid cell lines (Dunham et al., 2012) (Fig. 1A). Intriguingly, in tissue homogenates from frontal cortex and hippocampus and in cultured neurons, the $50 \mathrm{~kb}$ upstream fragment interacting with GAD1 TSS showed similar types of enrichment for H3K4me1 and H3K27 (Fig. 2A, browser tracks were loaded with data from $Z$ hu et al., 2013). Of note, such sharp peaks of $\mathrm{H} 3 \mathrm{~K} 27 \mathrm{ac}$ in conjunction with $\mathrm{H} 3 \mathrm{~K} 4 \mathrm{mel}$ and $\mathrm{H} 3 \mathrm{~K} 4 \mathrm{me} 3$ often define DNA elements that function as enhancers and regulate gene expression at sites of promoters positioned further upstream or downstream (Barski et al., 2007; Maston et al., 2012). Therefore, we hypothesized that GAD1-TSS ${ }^{-50 k b L o o p}$ is associated with the open chromatin fraction from the PFC, specifically with the H3K4me3-tagged GAD1 TSS interacting with nucleosomes positioned $50 \mathrm{~kb}$ further upstream that are epigenetically decorated with the same mark. In support of this hypothesis, GAD1-TSS-50kbLoop was readily detectable in PFC, a tissue with robust levels of GAD1 gene expression, in contrast to fibroblasts, which lack both the loop and detectable levels of GAD1 gene transcript (Fig. $1 B, C)$. To test this hypothesis directly, we used3C-ChIP Loop (Simonis et al., 2007), which is a modified version of the 3C approach to study chromosomal loopings in selected chromatin fractions enriched by immunoprecipitation. To this end, we immunoprecipitated HindIII digested chromatin from human PFC with anti-H3K4me3 antibody followed by PCR to interrogate ligation products representing GAD1-TSS ${ }^{-50 k b L o o p}$ (Fig. 1D). Indeed, pulldown with anti-H3K4me3 antibody resulted in much stronger enrichment for GAD1-TSS ${ }^{-50 k b L o o p}$ compared with pulldown with IgG control; furthermore, no PCR products from noncontiguous DNA sequences were observed in 3C-ChIP Loop experiments without ligase (Fig. 1D). We conclude that GAD1-TSS ${ }^{-50 k b L o o p}$ is a higher-order chromatin structure in which at least one or both sides of the loop are enriched with the H3K4me3 mark.

DNA elements in GAD1-TSS ${ }^{-50 k b L o o p}$ facilitate transcription As discussed above, the loop formation in chromosome $2 \mathrm{q} 31$, resulting in a physical interaction between the sequences surrounding the GAD1 TSS with DNA positioned $50 \mathrm{~kb}$ further upstream, is associated with GAD1 gene expression and open chromatin-associated histone methylation and acetylation in human PFC. Of note, the interacting DNA upstream of GAD1 is associated with sharp histone modification peaks associated with enhancer functions, including $\mathrm{H} 3 \mathrm{~K} 27 \mathrm{ac}$ and $\mathrm{H} 3 \mathrm{~K} 4 \mathrm{me} 1$ in peripheral cell lines and $\mathrm{H} 3 \mathrm{~K} 4 \mathrm{me} 3$ in PFC neurons, but in the absence of detectable (above background) cis-associated transcript at the peak site (Fig. 1A, red box; Fig. $2 A$ ) in our deeply sequenced total RNA extracts from PFC of six control subjects (Fig. 2B). These findings, together, would suggest that the upstream components of GAD1-TSS ${ }^{-50 k b L o o p}$ function most likely as enhancers by facilitating transcription when brought in proximal position to a gene promoter. To explore this, we focused on $115 \mathrm{bp}$ (chromosome 2: 171622200-171622315, HG19) which, based on TFSearch (http://www.cbrc.jp/research/db/TFSEARCH.html) (Heinemeyer et al., 1998), was highly enriched for a total of seven activating protein AP-1 early response transcription factor motifs (TGAG/CTCA), reflecting a much higher AP-1 motif density, or $60 \mathrm{AP}-1$ sites/kb, compared with the surrounding $15 \mathrm{~kb}$ with only 1.2 AP-1 sites/kb. The AP-1 motif is thought to mediate a significant portion of activity-dependent gene expression both in human and rodent PFC (Covington et al., 2010). We fused this 115 


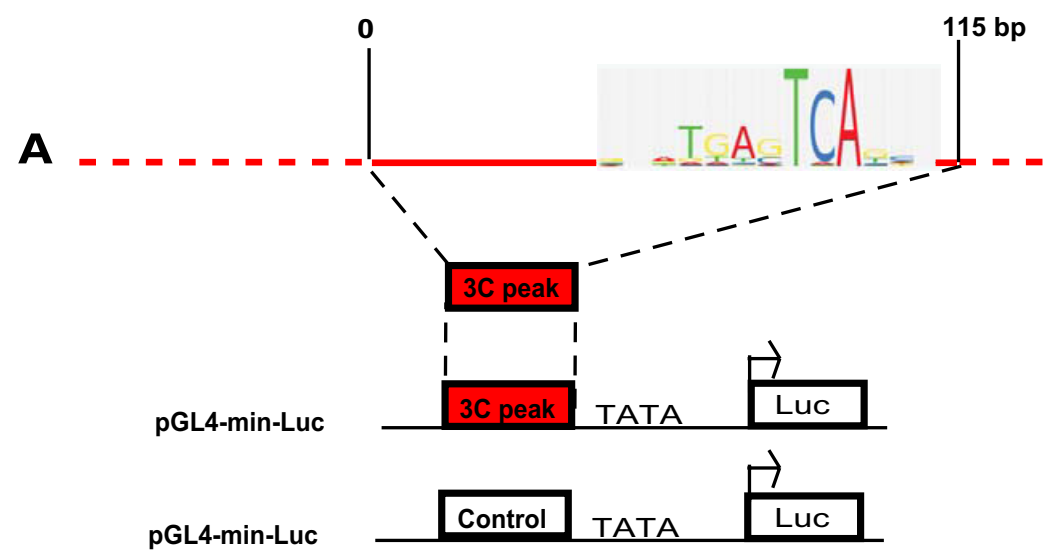

B

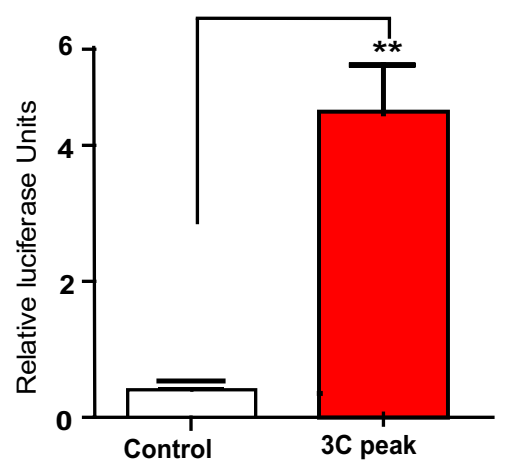

Figure 3. Intergenic DNA elements upstream of GAD1 facilitate transcription. $A$, Schematic description of luciferase reporter assay for 100 bp AP1-rich DNA element (chromosome 2: 171622200-171622300) (hg19). B, Bar graphs (mean \pm SD, $N=$ 3/group) represent luciferase activity in HEK293 cells expressing control (white) and $100 \mathrm{bp}$ DNA element (red bar). There is an $\sim 10$-fold increase in luciferase promoter fused to the AP1-enriched DNA element. ${ }^{* *} p<0.001$ (two-tailed $t$ test).

bp sequence 5' from a minimal promoter sequence and explored changes in transcriptional activity with a luciferase assay in HEK293 cells. Indeed, in 3 of 3 experiments, addition of the $100 \mathrm{bp}$ element resulted in a robust, $>10$-fold increase in luciferase expression and activity, compared with a control sequence void of AP-1 motifs (Fig. 3). These findings support the hypothesis that GAD1-TSS ${ }^{-50 k b L o o p}$ plays a role in the regulation of GAD1 transcription, by positioning upstream enhancer sequences in close proximity to GAD1 TSS.

\section{Higher-order chromatin in chromosome $2 \mathrm{q} 31$ \\ (GAD1-TSS ${ }^{-50 k b L o o p}$ ) emerges during the course of neural differentiation}

The above experiments suggest that physical interactions of open chromatin-associated DNA elements at the GAD1 locus, including GAD1-TSS ${ }^{-50 k b L o o p}$, are tissue specific and readily detectable in PFC. Of note, PFC is defined by robust expression of GAD1 RNA, in contrast to skin fibroblasts, which lack both detectable levels of gene expression and a tractable 3D chromosomal architecture at this locus (Fig. $1 B, C$ ). To further test the association between GAD1-TSS ${ }^{-50 k b L o o p}$ and active gene expression, we studied GAD1 higher-order chromatin and gene expression both in induced pluripotent stem cells (which were generated from one of the two fibroblast cultures used for 3C assays shown in Fig. $1 B, C$ ) and during their transition into differentiated neural cultures primarily comprised of microtubule-associated protein 2-immunoreactive neurons (Fig. $4 A, B$ ). Indeed, GAD1-TSS ${ }^{-50 k b L o o p}$, but no other DNA elements across a $220 \mathrm{~kb}$ segment of chromosome 2q31, showed a differentiationinduced, significant increase in interaction with the GAD1 TSS (Fig. 4B,C), in conjunction with increased GAD1 RNA expression (Fig. 4D). Levels of GAD1-TSS ${ }^{-50 k b L o o p}$ in the pluripotent stem cells were $\sim 50 \%$ lower compared with the neural cultures differentiated from them (Fig. 4D), which would be consistent with the notion that pluripotent cells maintain some degree of open chromatin, including histone acetylation and $\mathrm{H} 3 \mathrm{~K} 4$-trimethylation, at genes poised for expression during subsequent development and differentiation (Vastenhouw and Schier, 2012). The observed increase in GAD1-TSS ${ }^{-50 k b L o o p}$ structures upon neural differentiation was highly specific for this type of higher-order chromatin because no loop structures were observed in 3C assays from cell cultures without the ligation step (Fig. 4C). Furthermore, the physical interactions of noncontiguous DNA elements across a $75 \mathrm{~kb}$ intergenic portion on chromosome 16, which is insensitive to cellular differentiation (Ferraiuolo et al., 2010), were very similar between stem cells $(0.31 \pm$ $0.01)$ and differentiated neural cultures $(0.33 \pm 0.01)$.

\section{GAD1 higher-order chromatin is conserved in rodent and primate species}

We noticed that, in mouse cerebral cortex, histone $\mathrm{H} 3 \mathrm{~K} 4 \mathrm{me} 3$ landscapes around the chromosome 2qC2 Gad1 locus (Fig. 5A) show a striking resemblance to the epigenetic profile encountered in neuronal chromatin from human (Fig. 1A). Both mouse and primate cortex exhibits sharp $\mathrm{H} 3 \mathrm{~K} 4 \mathrm{me} 3$ peak profiles both at the GAD1/Gad1 TSS and a conserved CpG-rich sequence positioned $-55 \mathrm{~kb}(-50 \mathrm{~kb})$ upstream of Gad1 (GAD1) gene. The CpG-rich sequences at $-50 \mathrm{~kb}$ from the GAD1 TSS (HG19, chromosome 2: $171,627,226-171,628,062)$ include a 302 bp sequence that shows $88 \%$ sequence homology to mouse ( $\mathrm{mm}$ ), chromosome 2: $70,347,243-70,347,545)$. This degree of conservation is much higher than what is expected, given that the $10 \mathrm{~kb}$ of surrounding sequence shows a much lower degree, or $47.2 \%$, of sequence conservation ( $\mathrm{mm} 9$ chromosome 2: 70342243-70352545 to hg19 chromosome 2: 171621775-171629528). Furthermore, as for human PFC (tissue homogenate) (Fig. 2B), RNAseq from neuronal nuclei of mouse cerebral cortex did not reveal evidence for cisassociated transcript at the $\mathrm{H} 3 \mathrm{~K} 4 \mathrm{me} 3$ peak site positioned -55 $\mathrm{kb}$ upstream of Gad1 (mouse chromosome 2qC2) (Fig. 5A, red box). Furthermore, inspection of the H3K4me3 ChIp-seq datasets from PFC neurons and nonhuman primate prefrontal cortex, including macaque and chimpanzee (Shulha et al., 2012b), revealed epigenetic profiles at the Gad 1 locus very similar to those observed in human and mouse, with $\mathrm{H} 3 \mathrm{~K} 4 \mathrm{me} 3$ peaks limited to the Gad1 TSS and the conserved CpG-rich sequence positioned $\sim 50 \mathrm{~kb}$ further upstream: Rhesus macaque genome RM3, chromosome 12: 34110698-34112216 and chimpanzee (Pan troglodytes) genome PT3 chromosome 2B: 175198622-175200113. Given the conserved H3K4me3 landscapes between mouse and 


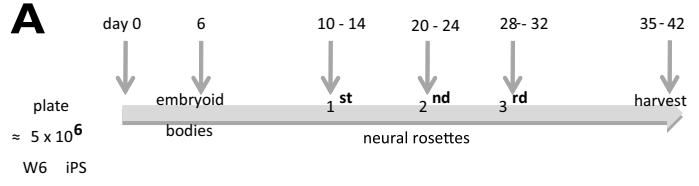

W6(iPS)

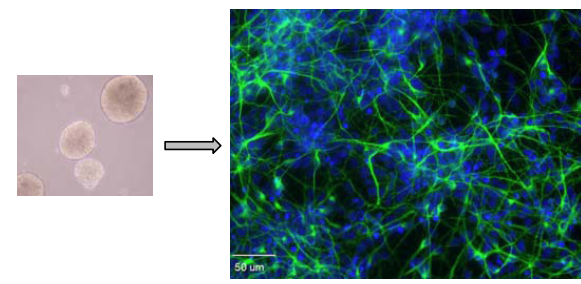

C

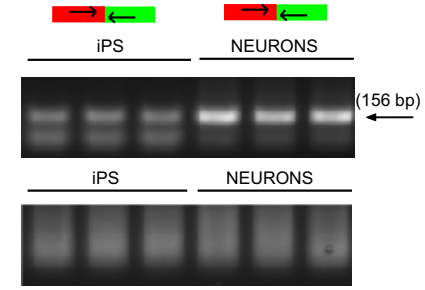

$\mathbf{B}$

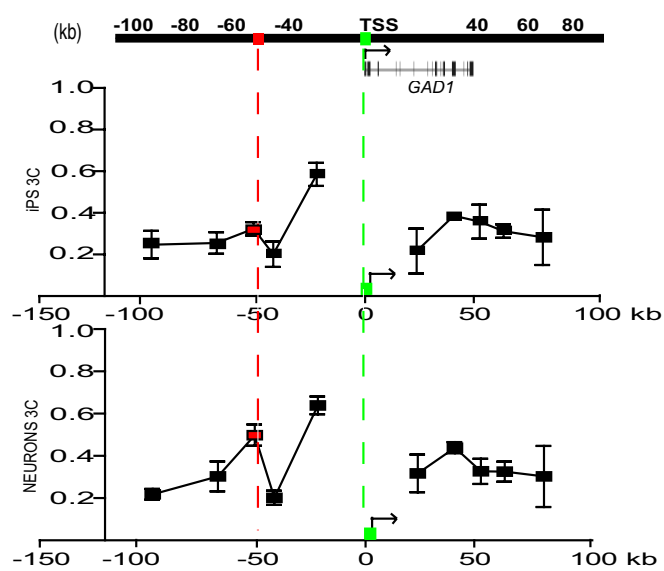

D

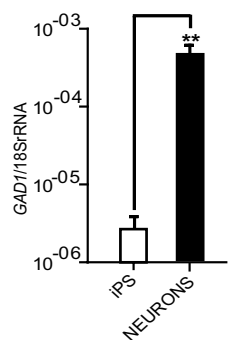

Figure 4. Developmental changes in GAD1 gene expression and chromatin architectures. $A$, Time line for generating of $1.5 \times 10^{7}$ differentiated cells, including a significant portion of microtubule-associated protein 2-immunoreactive cells (green, with blue [DAPI] counterstain) with neuronal morphology from input of $5 \times 10^{6}$ iPS (line W6). $\boldsymbol{B}$, Physical interactions of HindllI restriction fragments with the GAD1 TSS. There is increased interaction of sequences positioned $-50 \mathrm{~kb}$ upstream of GAD1 (red) with the TSS ( $\mathrm{green}$ ) in differentiated cells (bottom graph) but not iPS (top graph). C, Representative agarose gels from $156 \mathrm{bp} \mathrm{PCR} \mathrm{amplicons} \mathrm{of} \mathrm{primers} \mathrm{encompassing} \mathrm{GAD1-TSS}{ }^{-50 k b l o o p}$ with forward primer from $-50 \mathrm{~kb}$ sequence (red) and reverse primer from GAD1 TSS (green). The specific product is limited to 3 C assays with ( + ) but not without ( - ) ligase. $D$, Bar graphs (mean \pm SD, $N=3 /$ group) represent levels of (left) GAD1 RNA after normalization to 18 S RNA and (right) GAD1-TSS ${ }^{-50 k b l o o p}$. ${ }^{* *} p<0.001$ (two-tailed $t$ test).

primate brains, we hypothesized that 3D genome architectures in mouse cerebral cortex will include a homolog to the aforementioned GAD1-TSS ${ }^{-50 k b L o o p}$ from the human PFC, with a conserved enhancer sequence positioned $55 \mathrm{~kb}$ upstream of $\mathrm{Gad} 1$ directly interacting with the Gad1 promoter. Indeed, 3C assays from mouse cerebral cortex consistently revealed highest levels of interaction between the Gad1 TSS and the HindIII restriction fragment harboring the $\mathrm{H} 3 \mathrm{~K} 4 \mathrm{me} 3$-decorated, CpG-rich sequence positioned $\sim 55 \mathrm{~kb}$ further upstream (Fig. $5 A$ ). We conclude that GAD1-TSS ${ }^{-50 k b L o o p}$ is not unique to (human) chromosome $2 \mathrm{q} 31$ because very similar chromatin architectures, including Gad1-TSS ${ }^{-55 k \text { Loop }}$, are observed in mouse brain.

\section{Gad1-TSS ${ }^{-55 k b L o o p}$ is specific for GABAergic neuron chromatin and regulated by neuronal activity}

Of note, GAD1-TSS 50 kbLoop in human is lacking in fibroblasts but highly regulated in brain where it is tightly linked to open chromatin and active expression of the GAD1 gene (Fig. $1 B-D)$ and upregulated during the course of neuronal differentiation (Fig. 4). Therefore, we hypothesized that this chromosomal loop is a defining feature of GABAergic neurons, which in brain are the only cell type expressing high levels of GAD1/GAD67 GABA synthesis enzyme (and of a closely related gene, GAD2/GAD65). To address this question, we first generated $\mathrm{BAC}$ transgenic mice expressing GFP-conjugated histone $\mathrm{H} 2 \mathrm{~B}$ under control of the Gad2 gene promoter. We confirmed widespread expression of the transgene in cortical, hippocampal, and striatal GABAergic neurons (Fig. $5 B$ ) and then conducted $3 \mathrm{C}$ assays separately for $\mathrm{GFP}^{+}$and $\mathrm{GFP}^{-}$nuclei collected by fluorescence-activated nuclei sorting from cerebral cortex and hippocampus of adult
Gad2-H2BGFP mice. Strikingly, Gad1-TSS $55 k$ LLoop was highly specific for the population of GABAergic $\left(\mathrm{GFP}^{+}\right)$nuclei and completely absent in chromatin of non-GABAergic cells (Fig. $5 C$ ). This effect was consistently observed in 3 of 3 experiments. Therefore, Gad1-TSS 55 kbLoop, a higher-order chromatin structure associated with Gad1 gene expression, is part of the genome architecture specific for GABAergic neurons.

Activity-dependent regulation of Gad1/Gad67 gene expression is important for the orderly balance of inhibition and excitation in the cerebral cortex both in rodent and primates. For example, in monkeys, monocular deprivation of sensory input into visual cortex results after $5 \mathrm{~d}$ in a strong and prolonged downregulation of Gad1/Gad67 RNA in the ocular dominance columns innervated by the affected eye (Benson et al., 1994). In the rat, loss of hippocampal pyramidal neurons and hippocampal-prefrontal connectivity results in downregulated Gad1/ Gad67 expression in hippocampus (Shetty and Turner, 2001) and prefrontal cortex (Lipska et al., 2003). Decreased Gad1/ Gad67 expression, in turn, results in reduced levels of cytosolic GABA levels and lower amplitudes of miniature inhibitory synaptic postsynaptic currents (mIPSCs) (Lau and Murthy, 2012). Given that activity-regulated fine-tuning of Gad1/Gad67 expression is of pivotal importance for homeostatic plasticity both in primate and rodent cerebral cortex, we asked whether higherorder chromatin structures around the GAD1 locus, including GAD1-TSS ${ }^{-50 k b L o o p}$ and its mouse homolog, Gad1-TSS ${ }^{-55 k b L o o p}$ are involved in these mechanisms. We explored this question in primary cultures from mouse hippocampus, which were exposed for $15 \mathrm{~h}$ either to vehicle (DMSO) or the $\mathrm{GABA}_{\mathrm{A}}$ receptor antagonist picrotoxin (PTX) $(100 \mu \mathrm{M})$ to increase general neuronal 
A

(kb)

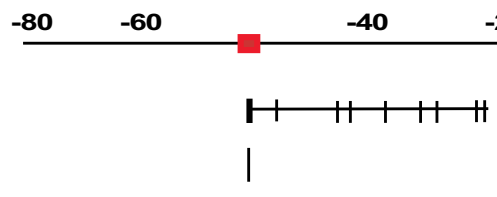

$-20$ o 20 40

\section{$\mathrm{CpG}$}
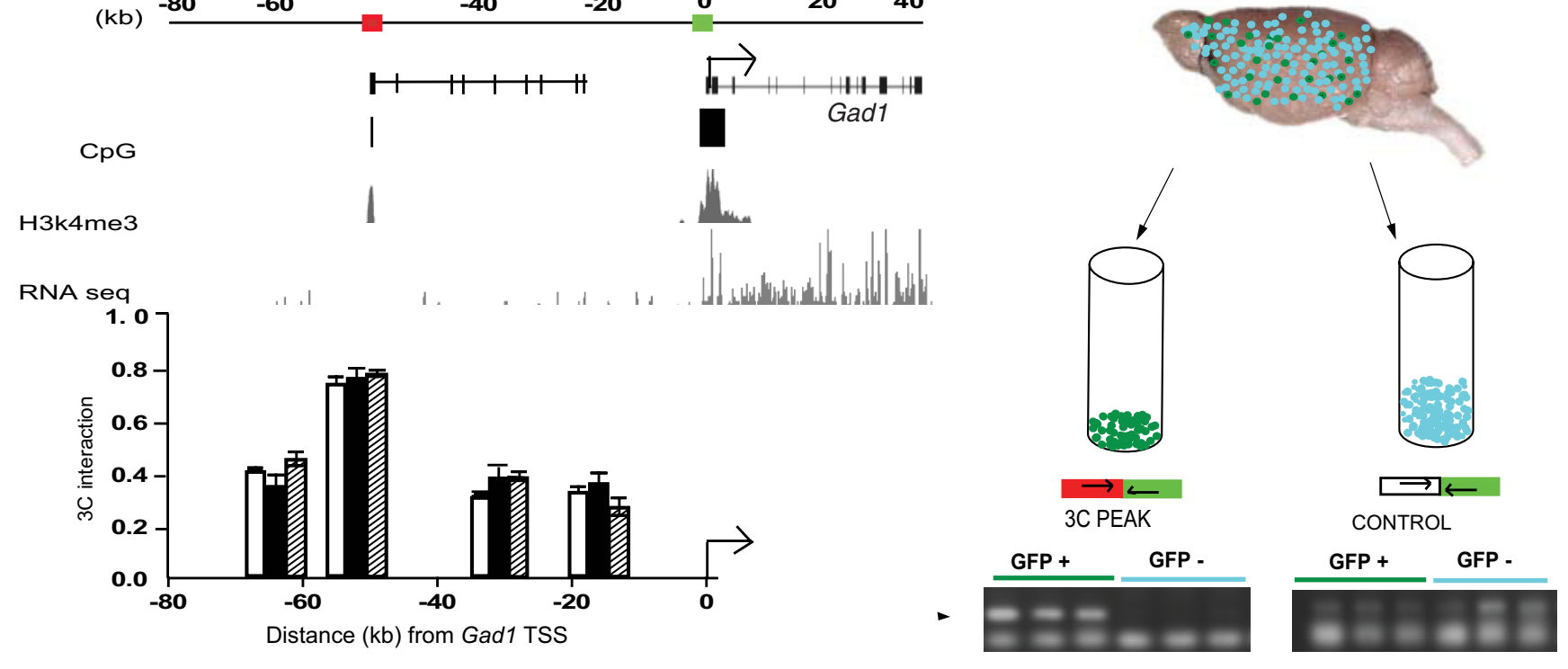

C

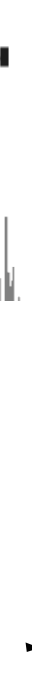

B
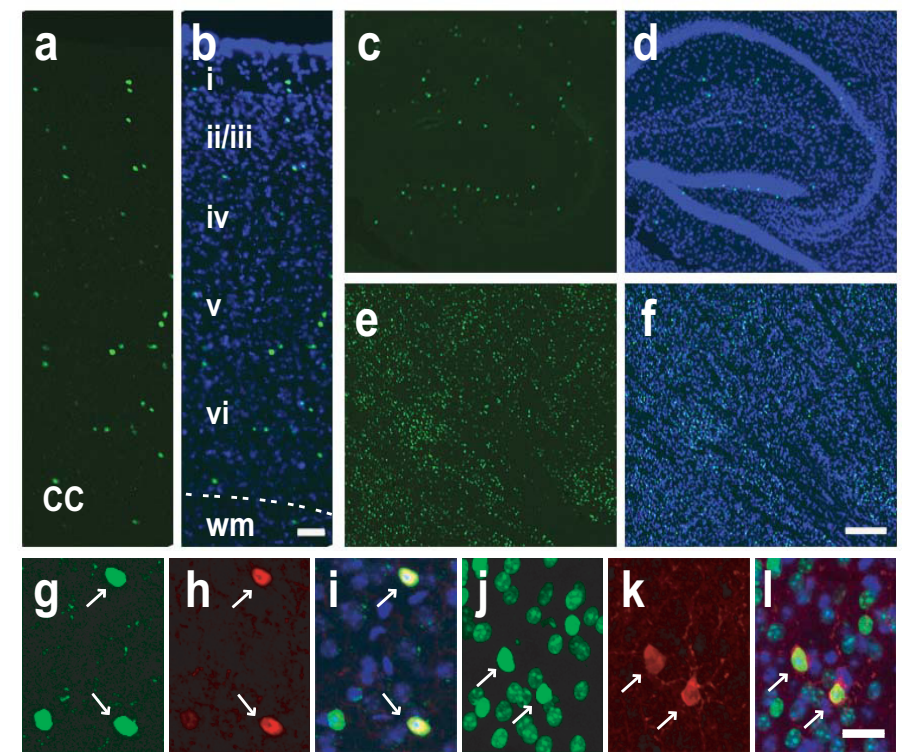
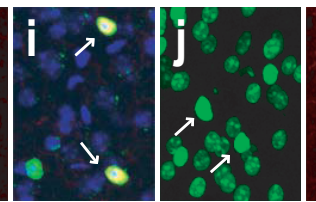

D
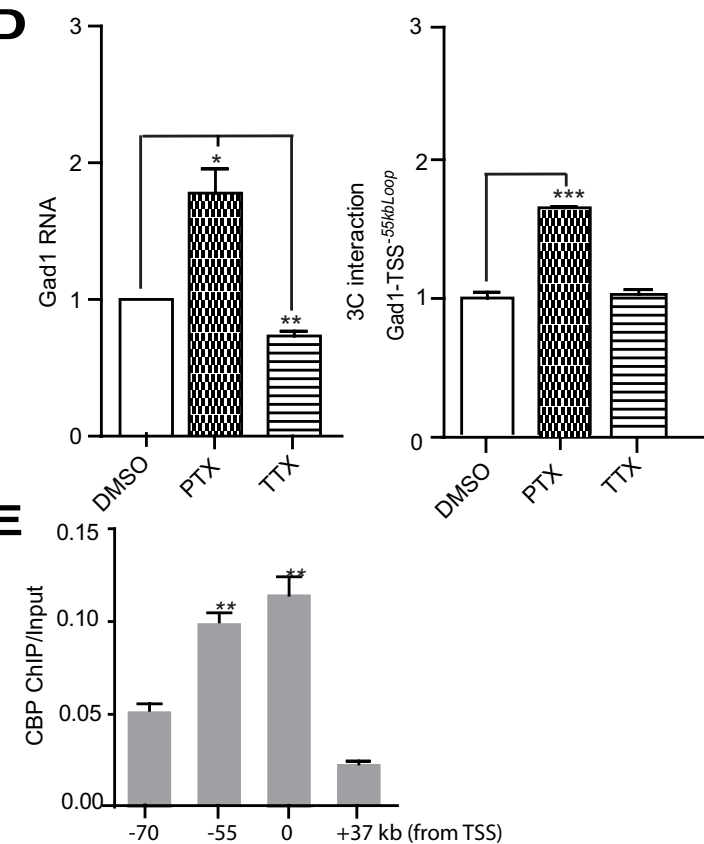

Figure 5. Gad1 higher-order chromatin is specific for GABAergic neurons and regulated by neuronal activity. A, Epigenetic profiles at 2qC2 (mouse) Gad1 locus in cerebral cortex, showing conservation of key features also found for human (chromosome 2q31.1) GAD1 locus. Mouse cerebral cortex, like human prefrontal cortex (Fig. 1), exhibits sharp H3K4me3 peak profiles both at Gad1 TSS and conserved CpG-rich sequence positioned 55 kb upstream of Gad 1 gene. Scale in kilobases for in correspondence with the UCSCGenome Browser map. H3K4me3 ChIP-seq trackfrom mouse cerebral cortex (Dixon et al., 2012), RNAseq track from sorted neuronal ( $\mathrm{NeuN}^{+}$) nuclei of adult cortex (see Materials and Methods). RNA expression is limited to Gad 1 gene body, whereas signal from upstream sequences does not exceed background. Bar graphs represent physical interactions between Gad1 TSS and noncontiguous DNA elements positioned further upstream, using anchor primer (TSS, green box primer 5' - GCCTTTGGAAACCAGCGTCCTICAGTGITT, mm9 chromosome 2: 70406539-70406568) and 4 primer combinations in 3 assays from adult mouse frontal cortex (white represents control group; black, clozapine; shaded, haloperidol; $N$ = 3/group, data are mean \pm SD). There are increased interaction frequencies between Gad1 TSS and (pG-rich sequence positioned $55 \mathrm{~kb}$ upstream of TSS in each of the 2 treatment and the control groups. $\boldsymbol{B}$, Fluorescence microscopy showing $(\boldsymbol{a}, \boldsymbol{b})$ vertical thickness of six-layered (i-vi; wm, White matter) cerebral cortex, $(\boldsymbol{c}, \boldsymbol{d})$ hippocampus, and $(\boldsymbol{e}, \boldsymbol{f})$ striatum of adult Gad2-H2BGFP transgenic mouse. The density and distribution of GFP ${ }^{+}$nuclei in all major telencephalic areas are consistent with the GABAergic phenotype. Representative examples of GFP ${ }^{+}(\boldsymbol{g}-\boldsymbol{i})$ cortical and $(\boldsymbol{j}-\boldsymbol{l})$ striatal neurons expressing $(\boldsymbol{h}, \boldsymbol{i})$ calretinin or $(\boldsymbol{k}, \boldsymbol{I})$ parvalbumin. Scale bars: $\boldsymbol{a}, \boldsymbol{b}, 50 \mu \mathrm{m} ; \boldsymbol{c}-\boldsymbol{f}, 200 \mu \mathrm{m} ; \boldsymbol{g}-\boldsymbol{I}, 20 \mu \mathrm{m}$. C, Transgenic Gad2-H2BGFP adult cortex was sorted into GFP ${ }^{+}$and GFP ${ }^{-}$nuclei followed by 3 C assays separately for both populations of nuclei, as indicated. Interaction frequency between Mouse Gad1 TSS region and Hindlll fragment positioned 55 kb upstream of Gad 1 TSS (red box in A, primer 5' - CTGGACTGGACAGTTGCTATTGCTACCTGA, mm 9 chromosome2: 70353571-70353600), both epigenetically decorated with H3K4me3 (A) was quantified by PCR, as indicated. The interaction is specificfor GFP ${ }^{+}$nuclei. There are very low interaction frequencies in both cell population for control sequence (primer 5'- TGITTGGTAGTGGCCTGGACTGCAGACAA, mm9 chromosome 2: 70383641-70383670). D, Activity-dependent regulation of higher-order chromatin at Gad1. Data from primary neuronal culture from mouse hippocampus, (left) Gad1 RNA and (right) 3 Cassays, showing chromosomal looping connecting TSS with $-55 \mathrm{~kb}$ upstream DNA elements (B, C) after $15 \mathrm{~h}$ of PTX or TTX treatment. $N=3$ experiments/group, mean \pm SEM, expressed relative to control (DMSO-treated cultures). Gad 1 RNA was consistently ( 3 of 3 experiments) upregulated in PTX-treated cultures and decreased after TTX, whereas Gad 3 C interactions were consistently increased in 3 of 3 experiments after PTX-induced increase in neuronal activity (one-way ANOVA, RNA: $F_{(2,12)}=26.74(p<$ $0.001)$, one sample $t$ test, DMSO versus PTX ( $p<0.05)$, DMSO versus TTX $(p<0.01), 3 C F_{(2,6)}=126.6(p<0.001)$, post hoc Bonferroni DMSO versus PTX ( $\left.p<0.001\right)$. E, CBP occupancy in chromatin from mouse cerebral cortex, expressed as chip-to-input ratio, at multiple positions at the Gad 7 locus, as indicated. CBP levels are significantly increased at - 55 kb and the interacting sequences at Gad 1-TSS, compared with $-77 \mathrm{~kb}$ upstream and $+37 \mathrm{~kb}$ downstream from TSS $\left(N=3\right.$ adult mice, mean \pm SD). One-way ANOVA: $F_{(3,8)}=88.76(p<0.001)$. Bonferroni-corrected: ${ }^{*} p<0.01$; $\left.{ }^{* *} p<0.001\right)$. 
activity, or the sodium channel blocker TTX $(1 \mu \mathrm{M})$ for silencing. As expected, Gad1/Gad67 RNA levels were consistently increased (3 of 3 experiments) by 70\% in PTX-treated cultures but decrease by $\sim 40 \%$ after TTX, compared with vehicle controls (Fig. $5 D$ ). This was associated with a consistent (3 of 3 experiments) $50 \%$ increase in physical interactions of the Gad1 TSS with its partnering sequences in Gad1-TSS ${ }^{-55 k b \text { Loop }}$ after treatment with PTX, compared with vehicle control (Fig. 5D). In contrast, Gad1TSS $^{-55 k b \text { Loop }}$ was not affected by TTX treatment. We conclude that Gad1 higher-order chromatin is dynamically regulated upon acute changes in neuronal activity, particularly in the context of increased excitation.

Our results show that DNA elements positioned 50 (human) or 55 (mouse) kb upstream of GAD1/Gad1 facilitate transcription and engage in a loop formation with the gene's TSS that is upregulated upon increased neuronal activity and transcription. Therefore, we hypothesized that both portions of the loop, including chromatin at site of the Gad1 TSS and its partnering sequences positioned $-55 \mathrm{~kb}$ further upstream, show increased occupancy for proteins, such as the CREB-binding protein and histone acetyltransferase, CREBBP/CBP, which, like its close homolog EP300, acts as a broad facilitator of gene expression (Alarcon et al., 2004; Korzus et al., 2004; Wood et al., 2006; Kim et al., 2010). To explore this, we conducted ChIP assays on adult mouse cerebral cortex and measured CBP binding in Gad1-TSS ${ }^{-55 k b L o o p}$ chromatin and additional positions in chromosome $2 \mathrm{qC} 2$. Indeed, CBP load was significantly higher at the Gad1-TSS and its partnering sequences $-55 \mathrm{~kb}$ further upstream, compared with chromatin positioned $-77 \mathrm{~kb}$ upstream, or $+37 \mathrm{~kb}$ downstream from the TSS (Fig. 5E).

\section{Decreased GAD1-TSS ${ }^{-50 k b L o o p}$ in prefrontal cortex of subjects with schizophrenia}

Subjects on the mood and psychosis spectrum, including many cases diagnosed with schizophrenia or bipolar disorder, are frequently affected by dysregulated gene expression in GABAergic interneurons in multiple brain regions (Guidotti et al., 2000; Konradi et al., 2011b). In the PFC (in particular, 30\% or $40 \%$ of subjects with schizophrenia) are affected by a robust deficit in GAD1/GAD67 gene expression (Volk et al., 2012). Consistent with this observation, open chromatin-associated histone modifications, including trimethylation of $\mathrm{H} 3 \mathrm{~K} 4$ and acetylation of other lysine residues, are decreased in nucleosomes surrounding the GAD1 TSS in the PFC of a subset of cases with schizophrenia (Huang et al., 2007; Tang et al., 2009). Given that the murine homolog of GAD1-TSS ${ }^{-50 k b L o o p}$ is specific for GABAergic neuron chromatin (Fig. 5C), and given the tight coregulation of this loop with GAD1/Gad1 expression both in and ex vivo in the human and the mouse (Figs. $1 B-D, 4 D$, and $5 D$ ), we hypothesized that this type of higher-order chromatin is altered in cases with schizophrenia that are affected by loss of GAD1 gene expression. To explore this, we conducted 3C assays on PFC tissue of 10 cases with schizophrenia and 7 controls, including 5 case-control pairs (matched for age/gender/autolysis time) previously found to show decreased GAD1/GAD67 RNA expression and H3K4 trimethylation in the disease case (Huang et al., 2007). Indeed, comparison of the general cohort of schizophrenics and controls, and separate analyses of the 5 case-control pairs revealed a significant (at least 35-45\%) decrease in physical interaction frequencies between the GAD1-TSS and its partnering sequences positioned $-50 \mathrm{~kb}$ further upstream (Fig. $6 A, B$ ). Consistent with the findings from the aforementioned postmortem studies that loss of transcription-associated epigenetic decorations of sequences
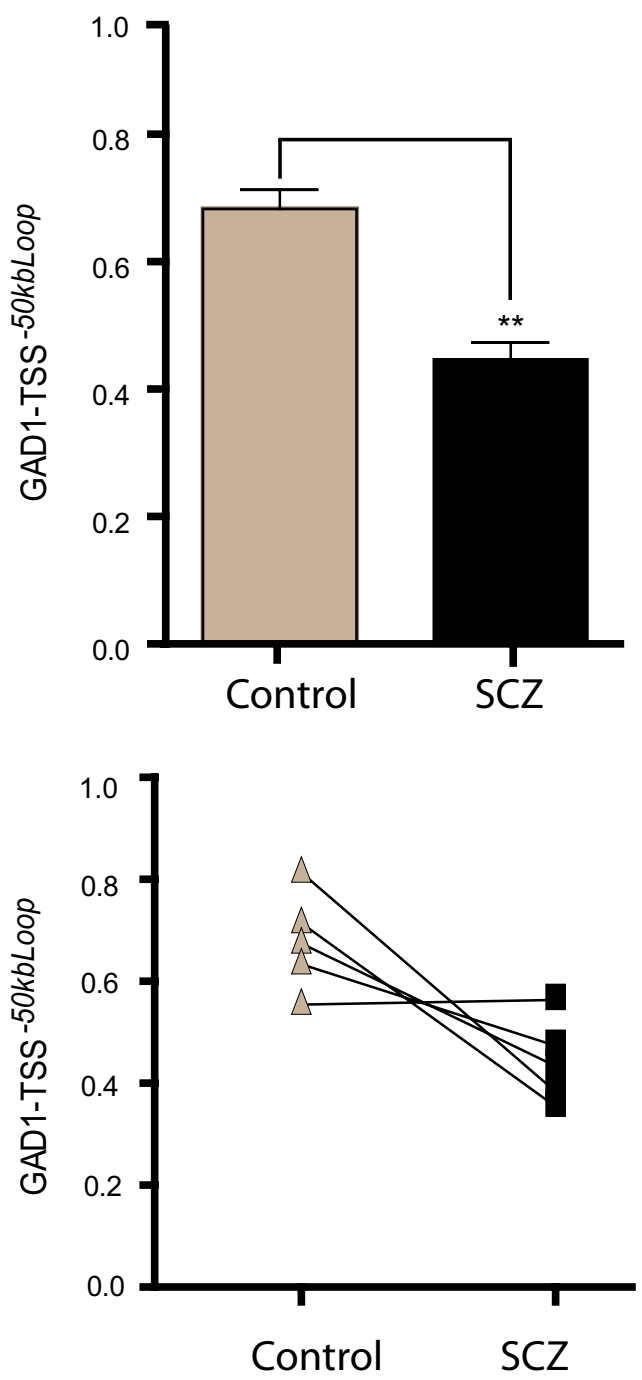

Figure 6. Higher-order GAD1 chromatin is altered in PFC of subjects with schizophrenia GAD1-TSS ${ }^{-50 k b L o o p}$ in PFC, as measured by PCR for GAD1 TSS with $-50 \mathrm{~kb}$ upstream sequences. Top, Bar graph, Mean 3 C interaction on $y$-axis generated from $N=10$ subjects with schizophrenia (SCZ) compared with $N=7$ controls. ${ }^{* *} p<0.001$ (two-tailed $t$ test). Bottom, Bar graph represents 3 interaction difference between $N=5 \mathrm{SCZ}$-control pairs matched for age, gender, and autolysis time. There are significant differences between schizophrenia and control group: $p<0.05$ (two-tailed $t$ test).

GAD1 TSS are not caused by antipsychotic medication (Huang et al., 2007; Tang et al., 2009), no quantitative changes in the strength of Gad1-TSS ${ }^{-55 k^{2} \text { Loop }}$ were observed in cerebral cortex of mice chronically treated with the conventional antipsychotic and dopamine $\mathrm{D}_{2}$-like receptor antagonist, or atypical antipsychotic clozapine (Fig. 5A).

\section{Discussion}

\section{Summary of results}

Mapping physical interactions of noncontiguous DNA elements across $200 \mathrm{~kb}$ surrounding the GAD1/GAD67 GABA synthesis enzyme gene locus in human PFC, we discovered a loop formation GAD1-TSS $50 k b$ Loop . The existence of GAD1-TSS ${ }^{-50 k b L o o p}$, and Gad1-TSS ${ }^{-55 k b \text { Loop }}$, as its mouse homolog, provides testimony for actively regulated higher-order chromatin structures in the human brain because GAD1-TSS ${ }^{-50 k b L o o p}$ was absent in 3C assays in which the critical DNA ligase step was omitted; furthermore, the loop was coregulated with GAD1 gene expression and therefore 
much stronger in cultured neurons compared with their undifferentiated precursors or the donors' skin fibroblasts. In mature cerebral cortex, the Gad genes are selectively transcribed in cortical interneurons; and indeed, our 3C assays on sorted nuclei revealed that Gad1-TSS ${ }^{-55 k b L o o p}$ was specific for GABAergic neurons. These findings, together, suggest that GAD1-TSS ${ }^{-50 k b L o o p}$ serves as a classical promoter/enhancer loop (Ong and Corces, 2011), by moving conserved DNA elements positioned $50 \mathrm{~kb}$ upstream of GAD1 into close proximity with the gene's TSS to facilitate its expression. In support of this model, the upstream interacting sequences are decorated with sharp peaks of histone $\mathrm{H} 3$ acetylated at lysine 27 (H3K27ac) in conjunction with monomethyl and trimethyl $\mathrm{H} 3 \mathrm{~K} 4(\mathrm{H} 3 \mathrm{~K} 4 \mathrm{me} / 3)$, which is of interest because co-occurrence of these histone modifications often defines enhancer elements (Barski et al., 2007; Zhou et al., 2011; Maston et al., 2012). In addition, we observed increased occupancy of the transcriptional facilitator, CBP/CREBBP, a protein that on a genome-wide scale preferentially locates both to gene proximal promoters and enhancers (Visel et al., 2009; Kim et al., 2010), at the two interacting sequences in Gad1-TSS ${ }^{-55 k b L o o p .}$. Furthermore, we deeply sequenced in the present study total RNA from tissue homogenates of human PFC, and from mouse cortex neuronal nuclei, and observed that none of the upstream DNA elements in GAD1-TSS ${ }^{-50 k b L o o p}$ and Gad1-TSS ${ }^{-55 k b L o o p}$ was transcribed in the cortex. Instead, these sequences harbored AP-1 transcription factor motifs; and, as expected for an enhancer sequence, when fused to generic promoters, we observed increased expression of the luciferase reporter.

\section{Implications for the neurobiology of schizophrenia}

Chromosomal loopings, including the GAD1-TSS ${ }^{-50 k b L o o p}$ described here, are among the most highly regulated supranucleosomal structures and pivotal for transcriptional regulation, by enabling distal regulatory enhancer or silencer elements positioned a few or many hundred kilobases apart from a gene, to interact directly with that specific promoter (Gaszner and Felsenfeld, 2006; Wood et al., 2010). Surprisingly, however, only very few studies explored loop formations in brain tissue (Horike et al., 2005; Dhar et al., 2009; Jiang et al., 2010; Yasui et al., 2011; Shen et al., 2012; Shulha et al., 2012b). Our study is the first to (1) monitor the emergence of higher-order chromatin at a GABAergic gene locus during the process of neural differentiation, and demonstrate that epigenetic architectures, including a specific promoter/enhancer loop, are (2) conserved between rodent and primate (including human) Gad1/GAD1, (3) sensitive to changes in neuronal activity, and (4) significantly dysregulated in PFC of subjects with schizophrenia affected by loss of GAD1 gene expression. It remains to be determined whether the weakening of prefrontal GAD1-TSS ${ }^{-50 k b L o o p}$ in a specific disease case is the result of genetic factors (including the GAD1 risk haplotypes in selected populations) (Addington et al., 2005; Lundorf et al., 2005; Straub et al., 2007; Ayalew et al., 2012) or the outcome of a developmental defect (Benes, 2012) or altered glutamate NMDA receptor signaling (Behrens et al., 2007; Homayoun and Moghaddam, 2007; Lisman et al., 2008; Belforte et al., 2010) or simply an adaptive response to cortical dysfunction, or combination thereof. In either case, a prolonged decrease of GAD1 is likely to be detrimental for higher cognitive function and the inhibitory networks in the cortex, given that Gad1 is important for homeostatic synaptic scaling by controlling GABA release and mIPSCs (Lau and Murthy, 2012), and the orderly formation of perisomatic innervation of cortical pyramidal neurons and basket neuron innervation fields in the adolescent cortex (Chattopadhyaya et al., 2007). Furthermore, GAD1 shares genetic risk factors that lead to alterations in the expression of the cation chloride cotransporters NKCC1/KCC2, which are of pivotal importance for the fine-tuning the inhibitory/excitatory effects of postsynaptic $\mathrm{GABA}_{\mathrm{A}}$ receptor-mediated currents (Hyde et al., 2011).

\section{Outlook}

In the present study, we first mapped physical interactions between noncontiguous DNA elements in postmortem brain specimens collected several hours after death, then explored these types of higher-order chromatin in cell culture and animal models. The implications of our study, when viewed as a proof of principle, are obvious: Only $1 \%$ of the human genome encodes protein. However, the vast majority of noncoding sequences are engaged in various open and repressive higher-order chromatin structures involved in genome organization and function (Lieberman-Aiden et al., 2009), but in the human brain these mechanisms until now remain completely unexplored. Because both the intergenic portions of the genome and its intronic sequences each harbor at least $40 \%$ of DNA polymorphisms and structural variants associated with complex traits and common medical (including psychiatric) conditions (Stranger et al., 2011), the findings presented here will pave the way for a more comprehensive mapping of $3 \mathrm{D}$ genome architectures in normal and diseased human brain. Such type of information, in conjunction with genome-wide DNA methylation and histone modification mappings (Mill et al., 2008; Kano et al., 2012; Labonte et al., 2012; Numata et al., 2012; Shulha et al., 2012a; Guintivano et al., 2013), will provide deep insights into the coordinated regulation of the epigenetic landscape of neuronal and glial genomes, including the role of DNA sequence variants, in specific disease cases diagnosed with schizophrenia and other psychiatric disease. Finally, the observation that the GAD1-associated chromosomal loop and the H3K4 trimethylation landscape associated with it are conserved between rodent and primate brain would suggest that higher-order chromatin, just as recently reported for DNA methylation, histone regulation, and transcription factor occupancies, shows robust homologies between species from different mammalian lineages (Xiao et al., 2012). Thus, the "genome in 3D" is fully open to study in human brain and preclinical models alike.

\section{References}

Addington AM, Gornick M, Duckworth J, Sporn A, Gogtay N, Bobb A, Greenstein D, Lenane M, Gochman P, Baker N, Balkissoon R, Vakkalanka RK, Weinberger DR, Rapoport JL, Straub RE (2005) GAD1 (2q31.1), which encodes glutamic acid decarboxylase (GAD67), is associated with childhood-onset schizophrenia and cortical gray matter volume loss. Mol Psychiatry 10:581-588. CrossRef Medline

Akbarian S, Huang HS (2006) Molecular and cellular mechanisms of altered GAD1/GAD67 expression in schizophrenia and related disorders. Brain Res Rev 52:293-304. CrossRef Medline

Akbarian S, Kim JJ, Potkin SG, Hagman JO, Tafazzoli A, Bunney WE Jr, Jones EG (1995) Gene expression for glutamic acid decarboxylase is reduced without loss of neurons in prefrontal cortex of schizophrenics. Arch Gen Psychiatry 52:258-266. CrossRef Medline

Alarcón JM, Malleret G, Touzani K, Vronskaya S, Ishii S, Kandel ER, Barco A (2004) Chromatin acetylation, memory, and LTP are impaired in CBP $+/-$ mice: a model for the cognitive deficit in Rubinstein-Taybi syndrome and its amelioration. Neuron 42:947-959. CrossRef Medline

Ayalew M, Le-Niculescu H, Levey DF, Jain N, Changala B, Patel SD, Winiger E, Breier A, Shekhar A, Amdur R, Koller D, Nurnberger JI, Corvin A, Geyer M, Tsuang MT, Salomon D, Schork NJ, Fanous AH, O’Donovan MC, Niculescu AB (2012) Convergent functional genomics of schizophrenia: from comprehensive understanding to genetic risk prediction. Mol Psychiatry 17:887-905. CrossRef Medline

Barski A, Cuddapah S, Cui K, Roh TY, Schones DE, Wang Z, Wei G, Chepelev 
I, Zhao K (2007) High-resolution profiling of histone methylations in the human genome. Cell 129:823-837. CrossRef Medline

Behrens MM, Ali SS, Dao DN, Lucero J, Shekhtman G, Quick KL, Dugan LL (2007) Ketamine-induced loss of phenotype of fast-spiking interneurons is mediated by NADPH-oxidase. Science 318:1645-1647. CrossRef Medline

Belforte JE, Zsiros V, Sklar ER, Jiang Z, Yu G, Li Y, Quinlan EM, Nakazawa K (2010) Postnatal NMDA receptor ablation in corticolimbic interneurons confers schizophrenia-like phenotypes. Nat Neurosci 13:76-83. CrossRef Medline

Benes FM (2012) A new paradigm for understanding gamma-aminobutyric acid cell pathology in schizophrenia? Biol Psychiatry 72:712-713. CrossRef Medline

Benson DL, Huntsman MM, Jones EG (1994) Activity-dependent changes in GAD and preprotachykinin mRNAs in visual cortex of adult monkeys. Cereb Cortex 4:40-51. CrossRef Medline

Brewer GJ, Torricelli JR, Evege EK, Price PJ (1993) Optimized survival of hippocampal neurons in B27-supplemented Neurobasal, a new serumfree medium combination. J Neurosci Res 35:567-576. CrossRef Medline

Chattopadhyaya B, Di Cristo G, Wu CZ, Knott G, Kuhlman S, Fu Y, Palmiter RD, Huang ZJ (2007) GAD67-mediated GABA synthesis and signaling regulate inhibitory synaptic innervation in the visual cortex. Neuron 54: 889-903. CrossRef Medline

Chen Y, Dong E, Grayson DR (2011) Analysis of the GAD1 promoter: transacting factors and DNA methylation converge on the $5^{\prime}$ untranslated region. Neuropharmacology 60:1075-1087. CrossRef Medline

Cheung I, Shulha HP, Jiang Y, Matevossian A, Wang J, Weng Z, Akbarian S (2010) Developmental regulation and individual differences of neuronal H3K4me3 epigenomes in the prefrontal cortex. Proc Natl Acad Sci U S A 107:8824-8829. CrossRef Medline

Covington HE 3rd, Lobo MK, Maze I, Vialou V, Hyman JM, Zaman S, LaPlant Q, Mouzon E, Ghose S, Tamminga CA, Neve RL, Deisseroth K, Nestler EJ (2010) Antidepressant effect of optogenetic stimulation of the medial prefrontal cortex. J Neurosci 30:16082-16090. CrossRef Medline

Dekker J (2006) The three 'C' s of chromosome conformation capture: controls, controls, controls. Nat Methods 3:17-21. CrossRef Medline

Deng W, Blobel GA (2010) Do chromatin loops provide epigenetic gene expression states? Curr Opin Genet Dev 20:548-554. CrossRef Medline

Dhar SS, Ongwijitwat S, Wong-Riley MT (2009) Chromosome conformation capture of all 13 genomic loci in the transcriptional regulation of the multisubunit bigenomic cytochrome $\mathrm{C}$ oxidase in neurons. J Biol Chem 284:18644-18650. CrossRef Medline

Dhara SK, Hasneen K, Machacek DW, Boyd NL, Rao RR, Stice SL (2008) Human neural progenitor cells derived from embryonic stem cells in feeder-free cultures. Differentiation 76:454-464. CrossRef Medline

Dixon JR, Selvaraj S, Yue F, Kim A, Li Y, Shen Y, Hu M, Liu JS, Ren B (2012) Topological domains in mammalian genomes identified by analysis of chromatin interactions. Nature 485:376-380. CrossRef Medline

Dunham I, Kundaje A, Aldred SF, Collins PJ, Davis CA, Doyle F, Epstein CB, Frietze S, Harrow J, Kaul R, Khatun J, Lajoie BR, Landt SG, Lee BK, Pauli F, Rosenbloom KR, Sabo P, Safi A, Sanyal A, Shoresh N, et al (2012) An integrated encyclopedia of DNA elements in the human genome. Nature 489:57-74. CrossRef Medline

Fatemi SH, Hossein Fatemi S, Stary JM, Earle JA, Araghi-Niknam M, Eagan E (2005) GABAergic dysfunction in schizophrenia and mood disorders as reflected by decreased levels of glutamic acid decarboxylase 65 and $67 \mathrm{kDa}$ and Reelin proteins in cerebellum. Schizophr Res 72:109-122. CrossRef Medline

Ferraiuolo MA, Rousseau M, Miyamoto C, Shenker S, Wang XQ, Nadler M, Blanchette M, Dostie J (2010) The three-dimensional architecture of Hox cluster silencing. Nucleic Acids Res 38:7472-7484. CrossRef Medline

Fung SJ, Webster MJ, Sivagnanasundaram S, Duncan C, Elashoff M, Weickert CS (2010) Expression of interneuron markers in the dorsolateral prefrontal cortex of the developing human and in schizophrenia. J Psychiatry 167:1479-1488. CrossRef Medline

Futai K, Doty CD, Baek B, Ryu J, Sheng M (2013) Specific trans-synaptic interaction with inhibitory interneuronal neurexin underlies differential ability of neuroligins to induce functional inhibitory synapses. J Neurosci 33:3612-3623. CrossRef Medline

Gaszner M, Felsenfeld G (2006) Insulators: exploiting transcriptional and epigenetic mechanisms. Nat Rev Genet 7:703-713. CrossRef Medline

Gheldof N, Tabuchi TM, Dekker J (2006) The active FMR1 promoter is associated with a large domain of altered chromatin conformation with embedded local histone modifications. Proc Natl Acad Sci U S A 103: 12463-12468. CrossRef Medline

Grayson DR, Guidotti A (2013) The dynamics of DNA methylation in schizophrenia and related psychiatric disorders. Neuropsychopharmacology 38:138-166. CrossRef Medline

Guenther MG, Jenner RG, Chevalier B, Nakamura T, Croce CM, Canaani E, Young RA (2005) Global and Hox-specific roles for the MLL1 methyltransferase. Proc Natl Acad Sci U S A 102:8603-8608. CrossRef Medline

Guenther MG, Levine SS, Boyer LA, Jaenisch R, Young RA (2007) A chromatin landmark and transcription initiation at most promoters in human cells. Cell 130:77-88. CrossRef Medline

Guidotti A, Auta J, Davis JM, Di-Giorgi-Gerevini V, Dwivedi Y, Grayson DR, Impagnatiello F, Pandey G, Pesold C, Sharma R, Uzunov D, Costa E, DiGiorgi Gerevini V (2000) Decrease in reelin and glutamic acid decarboxylase67 (GAD67) expression in schizophrenia and bipolar disorder: a postmortem brain study. Arch Gen Psychiatry 57:1061-1069. CrossRef Medline

Guintivano J, Aryee MJ, Kaminsky ZZ (2013) A cell epigenotype specific model for the correction of brain cellular heterogeneity bias and its application to age, brain region and major depression. Epigenetics 8:290-302. CrossRef Medline

Heinemeyer T, Wingender E, Reuter I, Hermjakob H, Kel AE, Kel OV, Ignatieva EV, Ananko EA, Podkolodnaya OA, Kolpakov FA, Podkolodny NL, Kolchanov NA (1998) Databases on transcriptional regulation: TRANSFAC, TRRD and COMPEL. Nucleic Acids Res 26:362-367. CrossRef Medline

Homayoun H, Moghaddam B (2007) NMDA receptor hypofunction produces opposite effects on prefrontal cortex interneurons and pyramidal neurons. J Neurosci 27:11496-11500. CrossRef Medline

Horike S, Cai S, Miyano M, Cheng JF, Kohwi-Shigematsu T (2005) Loss of silent-chromatin looping and impaired imprinting of DLX5 in Rett syndrome. Nat Genet 37:31-40. CrossRef Medline

Huang HS, Matevossian A, Whittle C, Kim SY, Schumacher A, Baker SP, Akbarian S (2007) Prefrontal dysfunction in schizophrenia involves mixed-lineage leukemia 1-regulated histone methylation at GABAergic gene promoters. J Neurosci 27:11254-11262. CrossRef Medline

Hyde TM, Lipska BK, Ali T, Mathew SV, Law AJ, Metitiri OE, Straub RE, Ye T, Colantuoni C, Herman MM, Bigelow LB, Weinberger DR, Kleinman JE (2011) Expression of GABA signaling molecules KCC2, NKCC1, and GAD1 in cortical development and schizophrenia. J Neurosci 31:1108811095. CrossRef Medline

Jiang Y, Matevossian A, Huang HS, Straubhaar J, Akbarian S (2008) Isolation of neuronal chromatin from brain tissue. BMC Neurosci 9:42. CrossRef Medline

Jiang Y, Jakovcevski M, Bharadwaj R, Connor C, Schroeder FA, Lin CL, Straubhaar J, Martin G, Akbarian S (2010) Setdb1 histone methyltransferase regulates mood-related behaviors and expression of the NMDA receptor subunit NR2B. J Neurosci 30:7152-7167. CrossRef Medline

Kano S, Colantuoni C, Han F, Zhou Z, Yuan Q, Wilson A, Takayanagi Y, Lee Y, Rapoport J, Eaton W, et al (2012) Genome-wide profiling of multiple histone methylations in olfactory cells: further implications for cellular susceptibility to oxidative stress in schizophrenia. Mol Psychiatry 2012 Advance online publication Retrieved Aug 28, 2012. doi:10.1038/ mp.2012.120. CrossRef Medline

Kim TK, Hemberg M, Gray JM, Costa AM, Bear DM, Wu J, Harmin DA, Laptewicz M, Barbara-Haley K, Kuersten S, Markenscoff-Papadimitriou E, Kuhl D, Bito H, Worley PF, Kreiman G, Greenberg ME (2010) Widespread transcription at neuronal activity-regulated enhancers. Nature 465:182-187. CrossRef Medline

Konradi C, Yang CK, Zimmerman EI, Lohmann KM, Gresch P, Pantazopoulos H, Berretta S, Heckers S (2011a) Hippocampal interneurons are abnormal in schizophrenia. Schizophr Res 131:165-173. CrossRef Medline

Konradi C, Zimmerman EI, Yang CK, Lohmann KM, Gresch P, Pantazopoulos H, Berretta S, Heckers S (2011b) Hippocampal interneurons in bipolar disorder. Arch Gen Psychiatry 68:340-350. CrossRef Medline

Korzus E, Rosenfeld MG, Mayford M (2004) CBP histone acetyltransferase activity is a critical component of memory consolidation. Neuron 42:961972. CrossRef Medline

Labonté B, Suderman M, Maussion G, Navaro L, Yerko V, Mahar I, Bureau A, Mechawar N, Szyf M, Meaney MJ, Turecki G (2012) Genome-wide epigenetic regulation by early-life trauma. Arch Gen Psychiatry 69:722-731. CrossRef Medline 
Lau CG, Murthy VN (2012) Activity-dependent regulation of inhibition via GAD67. J Neurosci 32:8521-8531. CrossRef Medline

Lewis DA, Curley AA, Glausier JR, Volk DW (2012) Cortical parvalbumin interneurons and cognitive dysfunction in schizophrenia. Trends Neurosci 35:57-67. CrossRef Medline

Li H, Handsaker B, Wysoker A, Fennell T, Ruan J, Homer N, Marth G, Abecasis G, Durbin R (2009) The Sequence Alignment/Map format and SAMtools. Bioinformatics 25:2078-2079. CrossRef Medline

Lieberman-Aiden E, van Berkum NL, Williams L, Imakaev M, Ragoczy T, Telling A, Amit I, Lajoie BR, Sabo PJ, Dorschner MO, Sandstrom R, Bernstein B, Bender MA, Groudine M, Gnirke A, Stamatoyannopoulos J, Mirny LA, Lander ES, Dekker J (2009) Comprehensive mapping of long-range interactions reveals folding principles of the human genome. Science 326:289-293. CrossRef Medline

Lipska BK, Lerman DN, Khaing ZZ, Weickert CS, Weinberger DR (2003) Gene expression in dopamine and GABA systems in an animal model of schizophrenia: effects of antipsychotic drugs. Eur J Neurosci 18:391-402. CrossRef Medline

Lisman JE, Coyle JT, Green RW, Javitt DC, Benes FM, Heckers S, Grace AA (2008) Circuit-based framework for understanding neurotransmitter and risk gene interactions in schizophrenia. Trends Neurosci 31:234-242. CrossRef Medline

Livak KJ, Schmittgen TD (2001) Analysis of relative gene expression data using real-time quantitative PCR and the $2(-$ delta delta C(T)) Method. Methods 25:402-408. CrossRef Medline

Lundorf MD, Buttenschøn HN, Foldager L, Blackwood DH, Muir WJ, Murray V, Pelosi AJ, Kruse TA, Ewald H, Mors O (2005) Mutational screening and association study of glutamate decarboxylase 1 as a candidate susceptibility gene for bipolar affective disorder and schizophrenia. Am J Med Genet 135B:94-101. CrossRef Medline

Maherali N, Ahfeldt T, Rigamonti A, Utikal J, Cowan C, Hochedlinger K (2008) A high efficiency system for the generation and study of human induced pluripotent stem cells. Cell Stem Cell 3:340-345. CrossRef Medline

Maston GA, Landt SG, Snyder M, Green MR (2012) Characterization of enhancer function from genome-wide analyses. Annu Rev Genomics Hum Genet 13:29-57. CrossRef Medline

Maunakea AK, Nagarajan RP, Bilenky M, Ballinger TJ, D'Souza C, Fouse SD, Johnson BE, Hong C, Nielsen C, Zhao Y, Turecki G, Delaney A, Varhol R, Thiessen N, Shchors K, Heine VM, Rowitch DH, Xing X, Fiore C, Schillebeeckx M, et al (2010) Conserved role of intragenic DNA methylation in regulating alternative promoters. Nature 466:253-257. CrossRef Medline

Miele A, Dekker J (2009) Mapping cis- and trans-chromatin interaction networks using chromosome conformation capture (3C). Methods Mol Biol 464:105-121. CrossRef Medline

Miele A, Gheldof N, Tabuchi TM, Dostie J, Dekker J (2006) Mapping chromatin interactions by chromosome conformation capture. Current protocols in molecular biology (Ausubel FM, et al., ed). Chapter 21, Unit 21:11.

Mill J, Tang T, Kaminsky Z, Khare T, Yazdanpanah S, Bouchard L, Jia P, Assadzadeh A, Flanagan J, Schumacher A, Wang SC, Petronis A (2008) Epigenomic profiling reveals DNA-methylation changes associated with major psychosis. Am J Hum Genet 82:696-711. CrossRef Medline

Numata S, Ye T, Hyde TM, Guitart-Navarro X, Tao R, Wininger M, Colantuoni C, Weinberger DR, Kleinman JE, Lipska BK (2012) DNA methylation signatures in development and aging of the human prefrontal cortex. Am J Hum Genet 90:260-272. CrossRef Medline

Ong CT, Corces VG (2011) Enhancer function: new insights into the regulation of tissue-specific gene expression. Nat Rev Genet 12:283-293. CrossRef Medline

Ribeiro de Almeida C, Stadhouders R, de Bruijn MJ, Bergen IM, Thongjuea S, Lenhard B, van Ijcken W, Grosveld F, Galjart N, Soler E, Hendriks RW (2011) The DNA-binding protein CTCF limits proximal Vkappa recombination and restricts kappa enhancer interactions to the immunoglobulin kappa light chain locus. Immunity 35:501-513. CrossRef Medline

Sara Y, Biederer T, Atasoy D, Chubykin A, Mozhayeva MG, Südhof TC, Kavalali ET (2005) Selective capability of SynCAM and neuroligin for functional synapse assembly. J Neurosci 25:260-270. CrossRef Medline

Schmidt MJ, Mirnics K (2012) Modeling interneuron dysfunction in schizophrenia. Dev Neurosci 34:152-158. CrossRef Medline

Shen Y, Yue F, McCleary DF, Ye Z, Edsall L, Kuan S, Wagner U, Dixon J, Lee
L, Lobanenkov VV, Ren B (2012) A map of the cis-regulatory sequences in the mouse genome. Nature 488:116-120. CrossRef Medline

Shetty AK, Turner DA (2001) Glutamic acid decarboxylase-67-positive hippocampal interneurons undergo a permanent reduction in number following kainic acid-induced degeneration of ca3 pyramidal neurons. Exp Neurol 169:276-297. CrossRef Medline

Shulha HP, Cheung I, Whittle C, Wang J, Virgil D, Lin CL, Guo Y, Lessard A, Akbarian S, Weng Z (2012a) Epigenetic signatures of autism: trimethylated H3K4 landscapes in prefrontal neurons. Arch Gen Psychiatry 69: 314-324. CrossRef Medline

Shulha HP, Crisci JL, Reshetov D, Tushir JS, Cheung I, Bharadwaj R, Chou HJ, Houston IB, Peter CJ, Mitchell AC, Yao WD, Myers RH, Chen JF, Preuss TM, Rogaev EI, Jensen JD, Weng Z, Akbarian S (2012b) Humanspecific histone methylation signatures at transcription start sites in prefrontal neurons. PLoS Biol 10:e1001427. CrossRef Medline

Simonis M, Kooren J, de Laat W (2007) An evaluation of 3C-based methods to capture DNA interactions. Nat Methods 4:895-901. CrossRef Medline Singh D, Chan JM, Zoppoli P, Niola F, Sullivan R, Castano A, Liu EM, Reichel J, Porrati P, Pellegatta S, Qiu K, Gao Z, Ceccarelli M, Riccardi R, Brat DJ, Guha A, Aldape K, Golfinos JG, Zagzag D, Mikkelsen T, et al (2012) Transforming fusions of FGFR and TACC genes in human glioblastoma. Science 337:1231-1235. CrossRef Medline

Stranger BE, Stahl EA, Raj T (2011) Progress and promise of genome-wide association studies for human complex trait genetics. Genetics 187:367-383. CrossRef Medline

Straub RE, Lipska BK, Egan MF, Goldberg TE, Callicott JH, Mayhew MB, Vakkalanka RK, Kolachana BS, Kleinman JE, Weinberger DR (2007) Allelic variation in GAD1 (GAD67) is associated with schizophrenia and influences cortical function and gene expression. Mol Psychiatry 12:854-869. CrossRef Medline

Tang B, Chang WL, Lanigan CM, Dean B, Sutcliffe JG, Thomas EA (2009) Normal human aging and early-stage schizophrenia share common molecular profiles. Aging Cell 8:339-342. CrossRef Medline

Tang B, Dean B, Thomas EA (2011) Disease- and age-related changes in histone acetylation at gene promoters in psychiatric disorders. Transl Psychiatry 1:e64. CrossRef Medline

Uhlhaas PJ, Singer W (2012) Neuronal dynamics and neuropsychiatric disorders: toward a translational paradigm for dysfunctional large-scale networks. Neuron 75:963-980. CrossRef Medline

Vastenhouw NL, Schier AF (2012) Bivalent histone modifications in early embryogenesis. Curr Opin Cell Biol 24:374-386. CrossRef Medline

Visel A, Blow MJ, Li Z, Zhang T, Akiyama JA, Holt A, Plajzer-Frick I, Shoukry M, Wright C, Chen F, Afzal V, Ren B, Rubin EM, Pennacchio LA (2009) ChIP-seq accurately predicts tissue-specific activity of enhancers. Nature 457:854-858. CrossRef Medline

Volk DW, Matsubara T, Li S, Sengupta EJ, Georgiev D, Minabe Y, Sampson A, Hashimoto T, Lewis DA (2012) Deficits in transcriptional regulators of cortical parvalbumin neurons in schizophrenia. Am J Psychiatry 169; 1082-1091. CrossRef Medline

Wood AJ, Severson AF, Meyer BJ (2010) Condensin and cohesin complexity: the expanding repertoire of functions. Nat Rev Genet 11:391-404. CrossRef Medline

Wood MA, Attner MA, Oliveira AM, Brindle PK, Abel T (2006) A transcription factor-binding domain of the coactivator CBP is essential for longterm memory and the expression of specific target genes. Learn Mem 13:609-617. CrossRef Medline

Xiao S, Xie D, Cao X, Yu P, Xing X, Chen CC, Musselman M, Xie M, West FD, Lewin HA, Wang T, Zhong S (2012) Comparative epigenomic annotation of regulatory DNA. Cell 149:1381-1392. CrossRef Medline

Yasui DH, Scoles HA, Horike S, Meguro-Horike M, Dunaway KW, Schroeder DI, Lasalle JM (2011) 15q11.2-13.3 chromatin analysis reveals epigenetic regulation of CHRNA7 with deficiencies in Rett and autism brain. Hum Mol Genet 20:4311-4323. CrossRef Medline

Zhang Y, Behrens MM, Lisman JE (2008) Prolonged exposure to NMDAR antagonist suppresses inhibitory synaptic transmission in prefrontal cortex. J Neurophysiol 100:959-965. CrossRef Medline

Zhou VW, Goren A, Bernstein BE (2011) Charting histone modifications and the functional organization of mammalian genomes. Nat Rev Genet 12:7-18. CrossRef Medline

Zhu J, Adli M, Zou JY, Verstappen G, Coyne M, Zhang X, Durham T, Miri M, Deshpande V, De Jager PL, Bennett DA, Houmard JA, Muoio DM, Onder TT, Camahort R, Cowan CA, Meissner A, Epstein CB, Shoresh N, Bern- 
stein BE (2013) Genome-wide chromatin state transitions associated with developmental and environmental cues. Cell 152:642-654. CrossRef Medline 